\title{
COMMENT
}

\section{THE CONSTITUTIONAL RIGHTS TO TRIAL BY JURY AND ADIMINISTRATIVE IMIPOSITION OF MONEY PENALTIES}

Each year, Congress and the state legislatures are confronted with the difficult task of designing government programs that can manage the complex problems facing our society. With imcreasing frequency, the legislative powers have responded to this challenge by delegating rulemaking authority to adininistrative agencies developed to cope with the coinplexities of a given policy area. This legislative delegation of power is often accompanied by statutory money penalties that can be inposed for violations of adininistrative regulations. ${ }^{1}$

Today, executive agencies annually initiate thousands of proceedings which result in the imposition of civil money penalties. ${ }^{2}$ Many of

\section{THE FOLLOWING CITATIONS WILL BE USED IN THIS COMMENT:}

Frank Irey, Jr., Inc. v. OSHRC, 519 F.2d 1200 (3d Cir. 1974) [hereinafter cited as Irey I], aff'd en banc, 519 F.2d at 1215 (3d Cir. 1975) [hereinafter cited as Irey II], cert. granted, 96 S. Ct. 1458 (1976);

Atlas Roofing Co., Inc. v. OSHRC, 518 F.2d 990 (5th Cir. 1975), cert. granted, 96 S. Ct. 1458 (1976) [hereinafter cited as Atlas Roofing];

K. Davis, Administrative LaW Treatise (1958) [hereinafter cited as K. Davis];

L. JAFFe, Judicial CoNTrol of ADMINISTRative ACtion (1965) [hereinafter cited as L. J J $\mathrm{AFE}_{\text {FF; }}$

5 J. MOORE, Federal Practice (2d ed. 1951) [hereinafter cited as J. Moore];

H. GOLDSCHMID, REPORT IN SUPPORT OF RECOMMENDATION 72-6: AN Evaluation of the Present and Potential Use of Civil Money Penalties As a Sanction by Federal Administrative Agencies, in 2 ReCOMmendations aNd RePORTS OF tHe AdMinistrative Conference of tHe United States (1972) [hereinafter cited as H. GOLDSCHMDD].

1. See, e.g., Federal Water Pollution Control Act, 33 U.S.C. $\$ 1161(f)(2)(1970)$ id. $\$ 1319$ (Supp. II 1972); Coal Mine Health and Safety Act, 30 U.S.C. $\$ \S 801,819$ (1970). For a catalogue of federal money penalty provisions, see H. GoLDscHMid 95764 (Appendix A).

2. In 1971, seven executive departments and thirteen administrative agencies initiated more than 60,000 actions for money penalties, see H. Goldschmm 953-54 (Appendix A, Chart II), and collected well in excess of $\$ 10$ inillion, see id. at 955-56 (Appendix A, Chart III). See also id. at 902 (Dep't of Agriculture handled over 1357 cases and collected more than $\$ 846,500$ in fiscal year 1970 ).

More recently, under the Occupational Safety and Health Act, 29 U.S.C. $\$ \$ 651$ et seq. (1970), the Department of Labor has issued about 67,000 citations which allege over 33,000 violations during the first $21 / 3$ years of enforcement. These citations 
these penalties are imposed by executive officers on the basis of their own findings of fact after administrative hearings where jury trials are normally not constitutionally required. ${ }^{3}$ In most of these proceedings, any question of a right to trial by jury is satisfied by provision for a de novo trial in federal court on application of the losing party. ${ }^{4}$ However, Congress has granted inore and more agencies the power to impose money sanctions subject only to limited judicial review. ${ }^{5}$ With the growing number of cases being leard by these agencies and the recent recommendation of the Admmistrative Conference of the United States that judicial review of other administrative adjudications be similarly limited, ${ }^{\circ}$ it is important to determine how far Congress may go in limiting defendants' rights to trial by jury by delegating adjudicative authority to the executive branch.

carried proposed penalties of almost $\$ 9$ million. See Comment, The Occupational Safety and Health Act of 1970: An Overview, 9 Gonzaga L. Rev. 477, 491 (1974). For a discussion of OSHA, see notes 19-39 infra and accompanying text.

3. K. DAvis $\$ 8.16$.

4. H. GoLDSCHMI 907, 936; L. JAFFE 99; see, e.g., Water Pollution Prevention and Control Act, 33 U.S.C.A. $\$ \S 1251,1319$ (b) (Supp. 1976); Coal Mine Health and Safety Act, 30 U.S.C. $\$ \$ 801,819$ (a) (3)-(4) (1970).

5. At least five federal agencies now have statutory authority to impose money penalties subject to only limited judicial review. Immigration and Naturalization Act, 8 U.S.C. $\S \S 1221$ (d), 1223(d), 1227(c), 1229-30, 1281, 1284-86, 1321-23 (1970); Federal Home Loan Bank Act, 12 U.S.C. \$ 1425a(d) (1970); Bald Eagle Protection Act, 16 U.S.C. § 668(b) (Supp. III, 1973); Endangered Species Act, 16 U.S.C.A. ₹ 1540a (Supp. 1974); Occupational Safety and Health Act, 29 U.S.C. $\$ \$ 660,666$ (1970); Fair Labor Standards Act Amendments of 1974, 29 U.S.C.A. \$ 216(e) (Supp. 1976) (expands OSHA into child labor area); 39 U.S.C. $\$ \$ 5206,5603-04$ (1970) (Post Office); Natural Gas Pipeline Safety Act, 49 U.S.C. \$§ 1671, 1675, 1678-79 (1970). See Irey I 1204 n.10; Atlas Roofing 1009, n.43. Only two of these statutes have been tested in the Supreme Court; both were upheld. Lloyd Sabaudo S.A. v. Elting, 287 U.S. 329 (1932) (INS); Elting v. N. German Lloyd, 287 U.S. 324 (1932); Oceanic Steam Navigation Co. v. Stranahan, 214 U.S. 320 (1909) (INS); Allman v. United States, 131 U.S. 31, 35 (1889) (Post Office); Great Northern Ry. v. United States, 236 F. 433, 433-34 (8th Cir. 1916) (Post Office).

Several of the states also have statutory schemes allowing administrative imposition of fines subject to only limited judicial review. E.g., Illinois Environmental Protection Act, IIL. REv. STAT. ch. 111 1/2, §̧§ 1041, 1042 (Smith-Hurd Supp. 1975); N.Y. INS. LAW \$ 95 (McKinney Supp. 1974); see Old Republic Life Ins. Co. v. Thacher, 12 N.Y.2d 48, 186 N.E.2d 554, 234 N.Y.S.2d 702 (1962).

In general, administrative resolution of issues of fact must be sustamed if supported by substantial evidence. The Occupational Safety and Health Act, for example, provides that the OSHRC's findings, "if supported by substantial evidence on the record considered as a whole, shall be conclusive." 29 U.S.C. $\$ 660$ (a) (1970). Discussions of the application of the substantial evidence rule can be found in L. JAFFE at 600 and K. DAvIS $\S \S 29.02,29.03$.

6. Recommendation 72-6: Civil Money Penalties as a Sanction in 2 RecommeNDations aNd Reports of tHe Administrative Conference of the UNITED States 66 (1972). 
The Third, ${ }^{7}$ Fifth, ${ }^{8}$ and Eighth ${ }^{8}$ Circuits have recently considered these issues in a series of cases which challenge the authority of the Occupational Health and Safety Review Commission (OSHRC) to impose civil money penalties under the Occupational Safety and Health Act (OSHA).$^{10}$ Each case involved a similar factual situation: the OSHRC issued a final order assessing a civil penalty on the basis of an administrative finding that a violation had occurred. ${ }^{11}$ Those against whom the penalties had been assessed appealed, argumg that the OSHRC procedure was unconstitutional on two alternative theories. ${ }^{12}$

7. Irey II; Bloomfield Mechanical Contracting, Inc. v. OSHRC, 37 AD. L. 2D 174 (3d Cir. 1975) (follows Irey $I$ and Irey II).

8. Atlas Roofing.

9. Beall Const. Co. v. OSHRC, 507 F.2d 1041 (8th Cir. 1974); American Smelting \& Ref. Co. v. OSHRC, 501 F.2d 504 (8th Cir. 1974).

10. See generally OSHA, 29 U.S.C. $\$ \$ 651$ et seq. (1970).

11. In Atlas Roofing, the case before the Fifth Circuit, the OSHRC had affirmed a $\$ 600$ penalty assessed by the Secretary of Labor for a failure to cover a roof opening adequately, a violation of 29 C.F.R. $\$ 1926.500$ (f)(S)(ii). The failure had resulted in the death of an employee. The accident prompted a Department of Labor inspection. Atlas Roofing 992.

In the Eighth Circuit cases, the OSHRC had assessed Beall Construction Co. a $\$ 620$ fine for one serious violation of suspension scaffolding regulations and four nonserious violations pertaining to stairway illumination, compressed gas storage and fire protection, Beall Const. Co. v. OSHRC, 507 F.2d 1041, 1042-43 (8th Cir. 1974), and American Smelting and Refining Co. had been fined $\$ 600$ for violations of OSHA's general duty clause (see note 22 infra), American Smelting \& Ref. Co. v. OSHRC, 501 F.2d 504, 505 (8th Cir. 1974). In each case the employer appealed.

The scope of the Third Circuit's ruling in Irey I and Irey II is slightly different. The Irey Co. was challenging the OSHRC's affirmation of a $\$ 5000$ sanction which had been imposed by an administrative law judge after his finding that a willful violation of standards regarding the snpport of trenches, 29 C.F.R. $\$ 1926.652$ (b) (1973), had occurred. A three judge panel of the appellate court affirmed the constitutionality of the Act's enforcement procedure, Irey I 1205 (2-1 decision), but reversed the administrative judgment that the violation was willful, finding instead that the Commission's analysis of that issue was based on an erroneous legal standard. Id. at 1207. The appellate court remanded the willful violation question for further administrative consideration consistent with its opinion while affirming a series of penalties assessed for non-willful violations. Id. Although the court's opinion reveals little consideration of the constitutional ramifications of OSHA's distinction between willful and non-willful violations, see notes 166-169, 177-179 infra and accompanying text, the fact that the question of whether a willful violation had occurred was remanded for administrative adjudication suggests that the court's consideration of OSHA's enforcement procedures included approval of the OSHRC's handling of willful violations.

The Third Circuit reheard Irey's seventh amendment arguments en banc, and a divided court sustained the panel decision to remand the factual issue of willful violations to the OSHRC, apparently in the belief that such an administrative adjudication of the issue would be constitutionally valid. See Irey $I I$ ( 6.4 decision).

The Bloomfield case concerned two serious and two nonserious violations of OSHA regulations. The court felt compelled to follow its earlier holding in Irey II. Bloomfield Mechanical Contracting, Inc. v. OSHRC, 37 AD. L.2D 174, 180-81 (3d Cir. 1975).

12. The thrust of these challenges to OSHA concerned the unavailability of trial by 
First, the nominally civil penalties were so criminal in nature that a jury trial was required in accordance with article III of the Constitution ${ }^{13}$ and the sixth amendment. ${ }^{14}$ Second, if criminal procedures were inappropriate, the seventh amendment's guarantee of a jury trial in civil cases $^{16}$ was applicable. All three circuits rejected the sixth amendment argument, holding that Congress had wide discretion to design methods for enforcing its legislative policies. ${ }^{16}$ The seventh amendment argument was also rejected on the ground that Congress liad the power to devise an administrative scheme for enforcing civil duties which precluded recourse to the judicial system. ${ }^{17}$ The importance of these decisions is heightened by recent suggestions that OSHA's enforcement policies be used as a model for other regulatory programs. ${ }^{18}$

This Comment will examine the extent to which the sixth and seventh amendments limit the use of administrative forums as factfinders in proceedings to impose money penalties. After a brief review of OSHA's penalty provisions, an examination will be made of traditionally employed precedents, principles relied on in analogous areas of the law, and the functions of civil and criminal juries. The purpose of this examination will be to develop general principles for application of the sixth and seventh amendments to legislative schemes providing for administrative adjudication and imposition of money sanctions. These principles will then be used to evaluate OSHA's penalty provisions.

jury at any point in the penalty imposition procedure. Traditionally, jury determination of issues of fact is precluded under such statutory schemes because administrative proceedings are incompatible with criminal procedure, see Helvering v. Mitchell, 303 U.S. 391, 402 (1938), and are beyond the scope of the seventh amendment which is restricted to those suits once triable at common law, U.S. ConsT. amend. VII. The correctness of this traditional approach is the subject of this Comment.

In OSHA, review of the OSHRC's findings is under the jurisdiction of the federal appellate courts, 29 U.S.C. $\$ 660$ (a) (1970), which do not conduct jury trials. Moreover, review is specifically limited by the substantial evidence rule. Id. See note 5 supra. For an outline of OSHA, see notes 19-39 infra and accompanying text.

13. "The Trial of all Crimes, except in Cases of Impeacliment, shall be by Jury; . . ." U.S. Const. art. III, \$ 2, cl. 3.

14. "In all criminal prosecutions, the accused shall enjoy the right to a speedy and public trial, by an impartial jury of the State and district wherein the crime shall have been committed . . . ." U.S. ConsT. amend. VI.

15. "In Suits at common law, where the value in controversy shall exceed twenty dollars, the right of trial by jury shall be preserved, and no fact tried by a jury, shall be otherwise reexamined in any Court of the United States, than according to the rules of the common law." U.S. CoNST. amend. VII.

16. See Atlas Roofing 1009-12; Irey I 1205; Beall Const. Co. v. OSHRC, 507 F.2d 1041, 1044 (8th Cir. 1974).

17. See Atlas Roofing 1011; Irey II 1218; Beall Const. Co. v. OSHRC, 507 F.2d 1041, 1044 (8th Cir. 1974).

18. See H. GoLDSCHMD 901, 930-31, 939; Atlas Roofing 994. 


\section{OSHA Penalty Provisions}

OSHA was enacted in an effort to reduce the spiraling number of job-related injuries and illnesses that threaten the lives of America's workers. ${ }^{19}$ In order to achieve this purpose, the Act provides for a comprehensive scheme of administrative regulation. Inspectors employed by the Department of Labor are authorized to visit work facilities $^{20}$ and to issue citations ${ }^{21}$ for violations of the Act. ${ }^{22}$ When violations are discovered, the Secretary of Labor may recommend four courses of action: (1) if the violation is non-serious, ${ }^{23}$ a penalty of up to $\$ 1000$ may be proposed, ${ }^{24}$ (2) should the violation be serious but not willful, the Act requires a penalty of up to $\$ 1000 ; ;^{26}$ (3) if a willful or repeated violation has occurred, a penalty of up to $\$ 10,000$ may be recommended; ${ }^{28}$ (4) finally, if a willful violation has caused the death

19. 29 U.S.C. $\$ 651$ (1970); see S. ReP. No. 91-1282, 91st Cong., 2d Sess. (1970); Meeds, A Legislative History of OSHA, 9 GonZaGa L. REv. 327 (1974).

20. 29 U.S.C. $\$ 657$ (a) (1970). The inspection procedures have been among the most controversial provisions of the Act. Compare Brennan v. Buckeye Indus., Inc., 374 F. Supp. 1350 (S.D. Ga. 1974), with Brennan v. Gibson's Prod. Inc., 407 F. Supp. 154 (E.D. Tex. 1976) (three-judge court); see Note, Brennan v. Buckeye Industries, Inc.: The Constitutionality of an OSHA Warrantless Search, 1975 DuRE L.J. 406; Comment, OSHA: Employer Beware, 10 Housron L. Rev. 426, 444-45 (1973). An inspection may be made as a result of an employee request, 29 U.S.C. $\S 657$ (f) (1970), or at the discretion of the inspector who needs neither a warrant nor probable cause. See id. § 657(a); Brennan v. Buckeye Indus., Inc., 374 F. Supp. 1350 (S.D. Ga. 1974); 29 C.F.R. \& 1903.3 (1975). Contra, Brennan v. Gibson's Prod., Inc., 407 F. Supp. 154 (E.D. Tex. 1976); Note, OSHA, supra, at 444-45. The inspections were intended to carry an element of surprise so that employers would be vigilant in taking safety precautions. Stender, Enforcing the Occupational Safety and Health Act of 1970: The Federal Government as a Catalyst, 38 LAW \& CoNTEMP. ProB. 641, 645-46 (1974). Indeed, surprise was valued so highly that Congress enacted criminal sanctions punishing anyone who gives advance notice of an inspection, 29 U.S.C. $\$ 666(f)$ (1970).

21. 29 U.S.C. $\$ 658(1970)$. A written citation is to "describe with particularity the nature of the violation, including a reference to the provision . . . violated" and "fix a reasonable time for the abatement of the violation." Id. \& 658(a). The inspector may also find that a violation exists but that it has no direct relationship to health or safety and issue a notice of a de minimis violation in lieu of a citation. Such violations carry no penalty. $I d$.

22. Citations may be issued for specific violations of standards promulgated by the Secretary of Labor, see id. $\$ \S 654(\mathrm{a})(2), 654(\mathrm{~b}), 655$, or for violations of the Act's broad general duty clause which requires an employer to "furnish to each of his employees employment and a place of employment which are free from recognized hazards .... Id. \& 654(a)(1).

23. The Act defines a serious violation as one causing "a substantial probability that death or a serious physical harm could result . . . unless the employer did not, and could not with the exercise of reasonable diligence, know of the presence of the violation." Id. $\S 666(\mathrm{j})$.

24. Id. $\S 666(\mathrm{c})$.

25. Id. $\$ 666(\mathrm{~b})$. The statutory definition of "serious" is set forth in note 23 supra.

26. Id. $\$ 666(\mathrm{a})$. 

the Commission, ${ }^{37}$ he may seek review of OSHRC's final order in the appropriate circuit court of appeals. ${ }^{38}$ Review of administrative findings of fact is limited; the Commission's findings "shall be conclusive" "if supported by substantial evidence on the record considered as a whole." 39

\section{Sixth Amendment Limitations}

The right to a jury trial in criminal cases is guaranteed in the body of the Constitution ${ }^{40}$ and reasserted by the Bill of Rights. ${ }^{41}$ According to the Supreme Court, these provisions "reflect a profound judgment about the way law should be enforced and justice should be administered" so that government controls are prevented froin becoming arbitrary and oppressive. ${ }^{42}$ The right to trial by jury guaranteed to criminal defendants is one aspect of a judicial system that was carefully designed to make certain that governmental power could not go unchecked. ${ }^{43}$ In order to achieve this purpose, the courts inust be diligent in examining any delegation of adjudicative power to administrative agencies which may deprive individuals of the procedural protections that are guaranteed by the Constitution. ${ }^{44}$

The ultimate question in determining the applicability of the sixth amendinent is whether the proceeding is "penal in nature."45 Although it is frequently asserted that the distinction between civil and criminal

37. If the employer does not contest the proposed citation and/or penalty, the OSHRC's order is nonreviewable. Id. $\$ 659$ (a).

38. Id. $\$ 660$ (a). The appeal must be brought within 60 days. Id. The Secretary of Labor is also empowered to seek review of some Commission orders. Id. $\S 660(\mathrm{~b})$.

39. Id. $\$ 660(\mathrm{a})$.

40. U.S. CoNST. art. III, \& 2, cl. 3, quoted at note 13 supra.

41. U.S. CoNST. amend. VI, quoted at note 14 supra.

42. Duncan v. Louisiana, 391 U.S. 145, 155 (1968).

43. Id. at 156.

44. The constitutional provisions for the right to a jury in a criminal trial are also applicable to the states through the due process clause of the fourteenth amendmeut. Id. at 158-59. This magnifies the importance of a careful analysis of the limits on legislative discretion in prescribing civil penalties since the same limits which apply to the federal government would presumably be applied to the states. Many of the states presently have agencies with adjudicative powers subject to only limited review. E.g., Environmental Protectiou Act, ILl. Rev. Stat. ch. 111 1/2, $\$ \S 1041,1042$ (Smith-Hurd Supp. 1975); Fair Employment Practice Act, Ilz. Rev. Stat. ch. 48, \$ 860 (Smith-Hurd 1966); N.Y. INs. LAw $\$ 5$ (McKinney Supp. 1974); see Old Republic Life Ins. Co. v. Thacher, 12 N.Y.2d 48, 186 N.E.2d 554, 234 N.Y.S.2d 702 (1962).

45. See, e.g., Kennedy v. Mendoza-Martinez, 372 U.S. 144, 167-69 (1963); Lipke v. Lederer, 259 U.S. 557, 562 (1922) (alleged tax held to be a money penalty); O'Sullivan v. Felix, 233 U.S. 318, 324 (1914) (civil and criminal money sanctions for personal assault). 
sanctions is merely one of statutory construction, ${ }^{46}$ such an approach is not helpful in delineating Congress' power to delegate adjudicative authority to admmistrative bodies. ${ }^{47}$ Even a clear legislative classification of a statute cannot so alter its fundamental nature as to enable it to impinge on constitutional protections, ${ }^{48}$ and this proposition is no less valid where only a pecuniary penalty is at stake. ${ }^{49}$ Surely no legislative label would enable Congress to authorize administrative inIposition of a $\$ 10,000$ civil penalty for robbing a federal bank. ${ }^{50}$ Congress may not circumvent the protections guaranteed criminal defendants by simply prescribing civil procedures for adjudicating alleged violations of the law. ${ }^{51}$ Such legislation would represent exactly the kind of arbitrary government conduct the sixth amendment was designed to prevent.

46. See, e.g., United States v. J.B. Williams Co., 498 F.2d 414, 421 (2d Cir. 1974). Such assertions often rely on language in Helvering v. Mitchell, 303 U.S. 391, 399 (1938). For a criticism of Williams' sixth amendment analysis, see Note, The Nature of Judicial Involvement in Civil Penalty Proceedings to Execute FTC Cease and Desist Orders, 1975 DuKE L.J. 501, 523-25.

47. This has already been recognized by the Fifth Circuit:

The Government naturally stresses the long accepted maxim that Congress may use either criminal or civil measures to control similar conduct. But although Congress has enormous flexibility in the selection of enforcement measures, the existence of both civil and criminal alternatives does not alone suffice to validate the statute. Similarly, the absence of any mention of punishment in the legislative history does not immunize the statute from further review. Atlas Roofing 1000 .

See Chamey, The Need for Constitutional Protections for Defendants in Civil Penalty Cases, 59 CoRnell L. Rev. 478, 494 (1974); Comment, The Imposition of Administrative Penalties and the Right to Trial by Jury-An Unheralded Expansion of Criminal Law, 65 J. CRIM. L. \& CRIM. 345, 352 (1974); Note, supra note 46, at 523-25.

48. McCulloch v. Maryland, 17 U.S. (4 Wheat.) 316, 421 (1819); United States v. J.B. Williams, 498 F.2d 414, 421 (2d Cir. 1974); Ashley v. Three Justices of Superior Court, 228 Mass. 63, 77, 116 N.E. 961, 966 (1917), appeal dismissed per curiam for want of jurisdiction sub nom. Ashley v. Wait, 250 U.S. 652 (1919); see Trop v. Dulles, 356 U.S. 86, 95 (1958).

49. See United States v. LeBeouf Bros. Towing Co., 377 F. Supp. 558 (E.D. La. 1974); United States v. Futura, Inc., 339 F. Supp. 162 (N.D. Fla. 1972); Charney, supra note 47, at 482. But see United States v. J.B. Williams, 498 F.2d 414, 421 (2d Cir. 1974); H. Goldschmid 915; Gellhorn, Administrative Prescription and Imposition of Penalties, 1970 WASH. U.L.Q. 265, 273-74 n.21.

50. Cf. Trop v. Dulles, 356 U.S. 86, 96 (1958); United States v. LeBeouf Bros. Towing Co., 377 F. Supp. 558, 563-64 (E.D. La. 1974) (hypothetical national drug abuse program).

51. This is not an unfair characterization. See Charney, supra note 47 , at 480 . One of the inter-house conferees who contributed to the compromises which led to the final OSHA legislation, Senator Dominick, defended the use of civil penalties during floor debate, explaining:

.. we have a civil not a criminal penalty for a willful or repeated violation. That has been treated with some care. We did it this way because I think most of us know how difficult it is to get an enforceable criminal penalty in these types of cases. Over and over again, the burden of proof under a crim- 


\section{The Petty Crime Exception}

Application of the sixth amendment is subject to one important caveat. Even when a particular proceeding is penal, trial by jury is not required if the crime at issue is "petty." 52 Thus, the petty crime exception may allow administrative law judges to impose monetary sanctions for criminal offenses. ${ }^{53}$ While the Supreme Court's position on the classification of money fimes as petty or non-petty is still unclear, ${ }^{54}$ a brief consideration of the two criteria normally considered in

inal-type allegation is so strong that you simply cannot get there, so you might as well have a civil penalty mstead of the criminal penalty and get the employer by the pocketbook if you cannot get him anywhere else. 116 CoNG. REC. 37,338 (1970).

A similar rationale was the basis for the more recent amendments to the Intercoastal Shipping Act, 46 U.S.C. $\$ \S 814,815,817,822,831,844$ (Supp. III, 1973), amending 46 U.S.C. $\$ \S 814,815,817,822,831,844$ (1970), which converted provisions for criminal penalties to civil penalties. See S. REP. No. 1014, 92d Cong., 2d Sess. 2-3 (1972).

52. This exception is an historic one that has been generally accepted as implicit in the concept of the right to jury which the constitutional conventions embodied in article III and the sixth amendment. Duncan v. Louisiana, 391 U.S. 145, 159-62 (1968); Cheff v. Schnackenberg, 384 U.S. 373, 379 (1966) (plurality opinion); Frankfurter \& Corcoran, Petty Federal Offenses and the Constitutional Guaranty of Trial by Jury, 39 HARv. L. Rev. 917 (1926); see Argersinger v. Hamlin, 407 U.S. 25, 29-30 (1972). But see Kaye, Petty Offenders Have No Peers!, 26 U. CHI. L. Rev. 245 (1959). See also Palmore v. United States, 411 U.S. 389, 413-14 (1973) (Douglas, J., dissenting); Baldwin v. New York, 399 U.S. 66, 74-76 (1970) (Black, J., concurring); District of Columbia v. Clawans, 300 U.S. 617, 633 (1937) (McReynolds, J., dissenting). As a result, the sixth ainendinent has been construed to guarantee a defendant's right to counsel, his right to a speedy and public trial, a right to be informed of the accusation against him, a right to confront and cross-examine witnesses, and a right to obtain coinpulsory process for obtaining witnesses in all criminal trials. The right to trial by jury, however, applies only where the crime is not petty. See Argersinger v. Hamlin, 407 U.S. 25 (1972) (established right to counsel in trial of petty offender).

53. See Coinment, supra note 47, at 358. The importance of this point must not be underestimated. Although this issue appears to have been ignored by all of the courts which have exalnined the procedural constitutionality of OSHA's enforcement mechanisin, the petty crime exception has the potential to resolve many of the sixth amendment challenges aimed at the unavailability of criminal juries in civil penalty cases. By holding the OSHA penalties petty, the courts can sidestep the weightier sixth annendinent issue of whether or not the particular sanction is penal in nature. A finding that all pecuniary penalties, or at least relatively sinall money fines (maximum fines of $\$ 500$ or $\$ 1000$, for example), are petty could obviate any question of the right to a criminal jury (in Irey $I$, for instance). Where trial by jury is not required and other elements of due process are available, there is no obvious impediment to conducting a criminal proceeding outside the state or federal courts. Cf. McKeiver v. Pennsylvania, 403 U.S. 528 (1971) (right to trial by jury not required in juvenile hearings); Doub \& Kestenbaum, Federal Magistrates for the Trial of Petty Offenses: Need and Constitutionality, 107 U. PA. L. REv. 443 (1959).

54. See Charney, supra note 47, at 501-04; see, e.g., Muniz v. Hoffinan, 422 U.S. 454 (1975) (discussing application of petty crime exception to a money fine for civil contempt); Douglass v. First Nat'l Realty Corp., No. 73-1137, at 11-17 (D.C. Cir. Mar. $3,1976)$. 
making this determination-"the seriousness with which society regards the offense" and "the severity of the maximum authorized penalty"indicates that not all money fines are necessarily petty. ${ }^{55}$

With respect to the severity of the maximum authorized penalty, decisions have generally begun with the statutory definition of a petty offense $^{56}$ as "[a]ny misdemeanor, the penalty for which does not exceed imprisonment for a period of more than six months, or a fime of not more than $\$ 500$, or both. . .." Ju Just as the Supreme Court has construed this definition so as to find a petty offense when no more than six months imprisonment is at issue, ${ }^{58}$ the statutory language suggests that a petty offense will exist where the potential fine does not exceed $\$ 500 .^{50}$ While recent Supreme Court decisions indicate that there is nothing thaumaturgic about the $\$ 500$ figure and that classification of monetary fines will vary according to their effect on a given defendant, ${ }^{, 0}$ it seems clear that not all money fimes will necessarily be classified as petty.

This view is supported by the increasingly serious offenses now being punished by monetary sanctions. ${ }^{01}$ Pettimess has never been a

55. See Baldwin v. New York, 399 U.S. 66, 68 (1970); Douglass v. First Nat'l Realty Corp., No. 73-1137, at 11-14 (D.C. Cir. Mar. 3, 1976). See also District of Columbia v. Clawans, 300 U.S. 617 (1937); cf. Frankfurter \& Corcoran, supra note 52, at $980-81$.

56. E.g., Duncan v. Louisiana, 391 U.S. 145, 161 (1968); Cheff v. Schnackenberg, 384 U.S. 373, 379 (1966); Douglass v. First Nat'1 Realty Corp., No. 73-1137, at 14-15 (D.C. Cir. Mar. 3, 1976).

57. 18 U.S.C. $\$ 1(3)$ (1970). A misdemeanor is defined as any offense that is not a felony, id. $\S 1(2)$, and a felony is any offense made "punishable by death or imprisonment for a term exceeding one year," id. $\$ 1(1)$.

58. Baldwin v. New York, 399 U.S. 66, 69 (1970) (" $[N]$ ]o offense can be deemed petty for purposes of the right to trial by jury where imprisonment for more than six months is authorized"); Duncan v. Louisiana, 391 U.S. 145, 161 (1968); Cheff v. Schnackenberg, 384 U.S. 373, 379-80 (1966).

59. See Douglass v. First Nat'l Realty Corp., No. 73-1137, at 17 (D.C. Cir. Mar. 3, 1976); United States v. R.L. Polk \& Co., 438 F.2d 377 (6th Cir. 1971) (holding that where a corporation was vulnerable to a fine of over $\$ 500$, the fine was not petty). There is a historical argument that the sixth amendment was never intended to cover sanctions where only property, not personal liberty, is at stake, Argersinger v. Hamlin, 407 U.S. 25, 45 n.2 (1972) (Powell, J., concurring); Kaye, supra note 52, at 274-77; see H. Goldschmid 915. But see Muniz v. Hoffman, 422 U.S. 454 (1975). Such a view seems unreasonable in view of the increasingly large money penalties imposed and the increasingly serions offenses which they are used to sanction.

60. See Muniz v. Hoffman, 422 U.S. 454, 477 (1975); Douglass v. First Nat'l Realty Corp., No. 73-1137, at 15-17 (D.C. Cir. Mar. 3, 1976).

61. Compare Doub \& Kestenbaum, supra note 53, at 445-46 (catalogue of present federal petty offenses), with OSHA, 29 U.S.C. $\$ 666$ (a) (1970) (civil penalty for willful violation of regulations designed to prevent serious harm to an employee). See also District of Columbia v. Colts, 282 U.S. 63 (1930) (reckless driving prosecution held 
rigidly fixed concept. ${ }^{62}$ Its dimensions vary from generation to generation so that "a penalty once thought to be mild may come to be regarded as so harsh as to call for the jury" even where it was not available in similar cases when the Constitution was adopted. ${ }^{63}$ Certainly, as the prisons become more crowded and the opposition to imprisonment as unnecessary and ineffective continues to mount, Congress and the courts will rely more and more heavily on monetary sanctions to punish serious offenses. Such punishments should not be classified as petty unless they actually fit the traditional conception of a petty crime as an act "which [does] not offend too deeply the moral purposes of the community, and [is] stigmatized by punishment relatively light." 64 Only by carefully applymg these factors on a case-by-case basis can the sixth amendment right to trial by jury remain an effective check against unjust government regulation.

Application of these general principles suggests that a further imquiry into the primary nature of OSHA's penalty provisions is in order. The relatively harsh penalty for willful violations ${ }^{65}$ and the grave nature of the conduct which constitutes a serious offense ${ }^{66}$ make it doubtful that these classes of violations could properly be characterized as petty. While the penalty for non-serious violations ${ }^{67}$ might be classified as petty, enabling a sanction to be imposed summarily, it is still necessary to consider whether or not that sanction is penal, for if it is not, its pettiness is irrelevant and the procedure for imposition must still surmount a seventh amendment challenge. ${ }^{68}$

\section{Applying the Sixth Amendment: When is a Sanction Penal?}

Determination of whether a given proceeding is in fact penal in nature has historically hinged upon a distinction between a wrong done to an individual and a wrong done to the public. ${ }^{69}$ This contrast

malum in se and therefore required right to trial by jury despite defendant's vulnerability to maximum penalty of only $\$ 100$ or 30 days in jail).

62. Frankfurter \& Corcoran, supra note 52, at 980.

63. District of Columbia v. Clawans, 300 U.S. 617 (1937).

64. Frankfurter \& Corcoran, supra note 52, at 980-81; cf. ABA ProJECT oN Standards for Criminal Justice, Standards Relating to Trial by Jury 20-21 (Approved Draft 1968); Model Penal Code $\$ 1.04(5)$, Comment (Proposed Draft 1962).

65. See OSHA, 29 U.S.C. $\$ 666(a)(1970)(\$ 10,000$ maximum penalty for each willful violation).

66. See id. $\$ \S 666(\mathrm{a})-(\mathrm{b})$. For the definition of a serious violation see note 23 supra.

67. See text accompanying notes 23-24 supra.

68. See notes 183-267 infra and accompanying text.

69. Huntington v. Attrill, 146 U.S. 657 (1892) was one of the earliest cases to make 
between the criminal and civil law is epitomized by the classification of contempt proceedings. While either form of contempt may result in incarceration, the object of the different proceedings is quite distinct:

A proceeding for civil contempt has as its object remedial punishment by way of a coercive imprisonment, or a compensatory fine, payable to the complainant. A proceeding for criminal contempt seeks punishnent to vindicate the authority of the court. ${ }^{70}$

The purpose of civil contempt and its sanctions is to benefit the individual rather than the state by compelling the wrongdoer to coinply with the law as established by the court. ${ }^{71}$ Criminal contempt is designed to

this distinction. There the Court relied upon a classification developed by Blackstone which distinguished between private wrongs involving the infringement of rights belonging to the individual and public wrongs which involve a violation of public rights and duties which benefit the community as a whole. Id. at 668-69, citing $3 \mathrm{~W}$. BLAcKsTONE, Commentaries *2. Thus, according to the early cases, whether an action was penal in nature depended on "whether the wrong to be redresscd is a wrong to the public, or a wrong to the individual." Id. at 668 . This dichotomy between public and private wrongs was the forerunner of the modern distinction between the criminal law as pena1 and the civil law as remedial or compensatory. See, e.g., United States ex rel. Marcus v. Hess, 317 U.S. 537, 548-49 (1943).

70. United States v. Schine, 125 F. Supp. 734, 736 (W.D.N.Y. 1954) (citations omitted); see Shillitani v. United States, 384 U.S. 364, 368-71 (1966); Douglass v. First Nat'l Realty Corp., No. 73-1137, at 6-7 (D.C. Cir. Mar. 3, 1976). See also R. Perkins, Criminal Law 532:33 (2d ed. 1969).

71. A similar distinction is found in the law of nuisance. A public nuisance is an "act or omission 'which obstructs or causes inconvenience or damage to the public in the exercise of rights cominon to all Her Majesty's subjects.' "W. Prosser, HANDBOOK ON THE LAW OF TORTS $\S 88$ at 583 (4th ed. 1971). It is a public wrong which is generally punished as a criminal offense. See id. A private nuisance on the other hand is a private wrong. The individual to whom the action accrues has been injured by the wrongful conduct in a way which differentiates him from other members of the community. His remedy lies in the civil law. See id. $\$ 86$ at 572-73, $\S 89$. The distinction closely follows the classification employed in Huntington v. Attrill, 146 U.S. 657 (1892), discussed at note 69 supra and accompanying text.

One possible exception to the general apphicability of the public/private distinction as a method of determining whether a statute is penal or civil in nature is found in recent environmental legislation protecting wildlife. Wild animals have traditionally belonged to all the citizens of a country in their collective capacity. As the representative of this collective, the government has the authority to exercise control over wild animals as a trust for the benefit of its citizens. "Implicit in this power was the right to regulate or absolutcly prohibit the taking of or traffic in, animals ferae naturae, if such action was deemed necessary for the protection or preservation of the public good." Fleinming v. United States, 352 F.2d 533, 536 (Ct. Cl. 1965). This position is most coinpletely detailed in Geer v. Connecticut, 161 U.S. 519 (1896), and has since been reaffirmed by the Supreme Court. See Tooiner v. Witsell, 334 U.S. 385, 399-403 (1948). This being the case, the state or federal government may be considered to own the endangered species and other wild animals which it chooses to protect, in which case a civil action may be appropriate to protect a private right even though it is exercised for the public good. Such an argument might justify the use of civil fines in such legislation as the Marine Mammal Protection Act, 16 U.S.C. $\$ 1375$ (a) (Supp. III, 
protect the public interest by deterring particular conduct and punishing its occurrence. ${ }^{72}$ The distinction provides the basis for determining the constitutional protections that inust be afforded an individual charged with contempt. ${ }^{73}$

The nodern approach for determining whether a particular penalty brings the sixth ainendment into play was formalized by the Supreme Court in Kennedy v. Mendoza-Martinez. ${ }^{74}$ At issue in that case was the constitutionality of provisions of the Nationality Act which provided for involuntary expatriation, without hearing, of persons leaving the United States to avoid a wartime draft. ${ }^{75}$ In holding that the Act violated the sixth amendment, ${ }^{76}$ the Court announced a two-step test to aid in the resolution of future sixth amendment questions. ${ }^{77}$ First, whenever possible, legislative purpose must be construed fron "objective manifestations" contamed in the legislative history of the provision; ${ }^{78}$ however, if sucl an inquiry does not produce "conclusive evidence of the legislative ainn," an objective appraisal of the statute itself must be nade. ${ }^{79}$

1973); Endangered Species Act, 16 U.S.C.A. $\$ 1540$ a (1974); Bald Eagle Protection Act, 16 U.S.C. $\$ 668$ (b) (Supp. III, 1973).

Use of such an exception would be severely limited. While a similar argument might be made in support of civil penalties for pollution control violators, precedent does not support such an argument. When the wrong is an undifferentiable imjury to the interests (as opposed to the property) of the general public, the appropriate action has generally been one for public nuisance, exposing the individual responsible to criminal liability.

72. Douglass v. First Nat'l Realty Corp. No. 73-1137, at 6-7 (D.C. Cir. Mar. 3, 1976); Lopiparo v. United States, 222 F.2d 897, 898 (8th Cir. 1955); Jeneau Spruce Corp. v. International Longshoremen's and Warehousemen's Union, 131 F. Supp. 866, 871 (D. Hawaii 1955). "Criminal contempt is a crime in the ordinary sense; it is a violation of the law, a public wrong which is punishable by fine or imprisonment or both." Bloom v. Illinois, 391 U.S. 194, 201 (1968); Shillitani v. United States, 384 U.S. 364, 368-71 (1966). See also R. PeRKINS, supra note 70, at 533-34.

73. See Bloom v. Illinois, 391 U.S. 194, 198-202 (1968) (established sixth amendment right to trial by jury in criminal contempt proceedings); Shillitani v. United States, 384 U.S. 364, 368-71 (1966).

74. 372 U.S. 144 (1963). A similar analysis had previously been used in Flemming v. Nestor, 363 U.S. 603, 612-21 (1960) (termination of deported aliens' old age benefits held not to require a trial with all the incidents of the sixth amendment).

75. See Nationality Act of $1940 \$ 401(\mathrm{j}), 58$ Stat. 746 (1944), and its successor and counterpart, Immigration and Nationality Act of $1952 \S 349$ (a)(10), 66 Stat. 163, 26768 (1952).

76. 372 U.S. at 165.

77. Id. at $168-69$.

78. Id. at 169; see United States v. Futura, Inc., 339 F. Supp. 162, 165 (N.D. Fla. 1972); Telephone News Sys., Inc. v. Illinois Bell Tel. Co., 220 F. Supp. 621,630 (N.D. IIl. 1963) (tliree-judge court), aff'd per curiam, 376 U.S. 782 (1964).

79. 372 U.S. at 169; see Flemming v. Nestor, 363 U.S. 603, 617 (1960); United States v. LeBeouf Bros. Towing Co., 377 F. Supp. 558, 563 (E.D. La. 1974); United States v. Futura, Inc., 339 F. Supp. 162, 165 (N.D. Fla. 1972); Telephone News Sys., 
The analysis is designed to determine whether the legislative aim in providing a sanction was to punish an individual for unlawful conduct or to regulate the conduct in question. ${ }^{80}$ Thus, in order for a civil money penalty to pass the test of Mendoza-Martinez, it must have a legitimate remedial purpose. ${ }^{81}$ That is, it inust either compensate an injured party for a loss or serve to abate a hazard which violates the law.

\section{Compensatory Penalties}

It has long been recognized that compensation of the government for its injuries is a legitimate function of the civil law. ${ }^{82}$ Reimbursement for loss is the normal civil remedy for a private injury. ${ }^{83}$ While the situation may seem somewhat different when the injured party is the government and has legislated its compensation in advance, Congress' authority to fix appropriate fines for private injuries is firmly established, ${ }^{84}$ and that power exists whether the wrong committed is against the government or against a private individual..$^{85}$ Despite their relative severity, the Court has consistently refused to invalidate such sanctions unless the ineasure of recovery fixed by Congress is unreasonably excessive. ${ }^{86}$ Thus, the power to tax puts the government and the

Inc. v. Illinois Bell Tel. Co., 220 F. Supp. 621 (N.D. Ill. 1963) (three-judge court), aff'd per curiam, 376 U.S. 782 (1964).

80. United States v. LeBeouf Bros. Towing Co., 377 F. Supp. 558, 562 (E.D. La. 1974); United States v. Futura, Inc., 339 F. Supp. 162, 165 (N.D. Fla. 1972); Telephone News System, Inc. v. Illinois Bell Tel. Co., 220 F. Supp. 621, 630 (N.D. Ill. 1963) (three-judge court), aff'd per curiam, 376 U.S. 782 (1964); see Kennedy v. MendozaMartinez, 372 U.S. 144 (1963); Flemming v. Nestor, 363 U.S. 603, 614 (1960).

81. See 372 U.S. at 169; Flemming v. Nestor, 363 U.S. 603, 612-16 (1960); Trop v. Dulles, 356 U.S. 86, 96 (1958).

82. Cotton v. United States, 52 U.S. (11 How.) 241, $243-44$ (1850); sce United States ex rel. Marcus v. Hess, 317 U.S. 537, $549-50$ (1943); Helvering v. Mitchell, 303 U.S. 391, 399-401 (1938).

83. See gencrally D. Dobis, Handbook on the Law of Remedies 135 (1973); C. McCormick, HaNdBoOK on the LaW of Damages 23 (1935).

84. See Brady v. Daly, 175 U.S. 148, 154-56 (1899) (copyright law setting minimum recovery for infringement held not penal).

85. Sec United States ex rel. Marcus v. Hess, 317 U.S. 537, 548-52 (1943) (statute requiring payment of costs, $\$ 2000$ and double damages as a civil penalty for fraudulent government bidding). See also Rex Trailer Co. v. United States, 350 U.S. 148 (1956); Cotton v. United States, 52 U.S. (11 How.) 241 (1850). The civil law binds all to all, and damages that are difficult to assess may be defined by Congress as it defines civil relationships. Brady v. Daly, 175 U.S. 148 (1899).

Congress' power to set compensation for injury to the government is closely analogous to the prerogative of private parties to bind themselves through liquidated damage clauses designed to set reasonable damages for injuries which will be difficult to evaluate in money terms; see id. at 151; Uniform Commercial Code $\$$ 2-718; RESTATEMENT OF CONTRACTS $\$ 339$ (1932).

86. Helvering v. Mitchell, 303 U.S. 391, 396-401 (1938) (fine for $\$ 728,709.84$ tax 
taxpayer in a debtor-creditor relationship, ${ }^{87}$ and a civil proceeding is the appropriate vehicle for resolution of disputes over the debt. ${ }^{88}$ Similarly, the compensation rationale justifies Congress' frequent use of civil inoney penalties as a form of liquidated damages when government contractors do not perform in accordance with their agreenents, ${ }^{89}$ or government licensees do not coinply with restrictions on their hicenses. ${ }^{90}$

As long as the primary purpose of an action is the compensation of a victim by his wrongdoer, it can be conducted under the rules of civil procedure regardless of other punitive effects which may inhere in the available remedy. ${ }^{91}$ Holdings which approve an eleinent of deterrence

deficiency was an additional $\$ 364,354.92$; upheld by the Court despite the fact that it did far more than indemnify the Government for its loss). The more recent cases rely on a standard of "unreasonable excessiveness" which is consistent with Helvering. E.g., One Lot Emerald Cut Stones and One Ring v. United States, 409 U.S. 232, 237 (1972) (forfeiture of stones and ring was not an excessive penalty for failure to declare them when they were brought into the country); Rex Trailer Co. v. United States, 350 U.S. 148,154 (1956) (\$2000 plns double dainages for fraudulent purchase of Government surplus was not excessive enongh to make the penalty penal).

87. See Helvering v. Mitchell, 303 U.S. 391, 401 (1938).

88. United States ex rel. Marcus v. Hess, 317 U.S. 537, 549-50 (1943). See generally D. DoBBS, supra note 83, at 232-35; J. MOORE $\pi$ 38.11[5].

89. E.g., Rex Trailer Co. v. United States, 350 U.S. 148, 154 (1956). The contractual rationale justifies the use of civil sanctions by two of the administrative agencies which are presently authorized to impose penalties subject to only limited judicial review. The Post Office is presently authorized to penalize its carriers for failure or refusal to transport the mail without invoking the power of the courts. See 39 U.S.C. $\S \S 5206,5603,5604(1970)$. The validity of these provisions is well settled by the courts. Allman v. United States, 131 U.S. 31, 35 (1889); Great Northern Ry. v. United States, 236 F. 433, 433-34 (8th Cir. 1916). These statutory provisions are analogous to liquidated damages and are incidents of the relationship between the government and another contracting party. See note 85 supra.

A more recent illustration of this rationale is found in the Federal Home Loan Bank Board's (FHLBB) authority to impose penalties on banks involved in the home loan bank program or msured by the Federal Savings and Loan Insurance Corp. 12 U.S.C. \& 1425a(d) (1970) (penalty for a deficiency under the Act's liquidity requirements). In return for loans and/or insurance the banks agree to comply with the regulation authorized by the Act. Compare 12 U.S.C. \$ 1424, 1430 (1970) with 12 U.S.C. \$ $1425 \mathrm{a}$ (d) (1970). "The counsel of the FHLBB reported that there has never been a court appeal' but that 'review would be limited to considering whether the Board had acted arbitrarily or capriciously." "H. GoLDSCHMID 952 n.5.

90. E.g., 47 U.S.C. $\$ 503(b)$ (1970) (penalties for violations by broadcast licensees). The license or pernit subjects its holders to certain responsibilities inherent in the license. See id.

Professor Jaffe has commented on the utility of such combinations of licensing and fining powers: "To be sure, when the revocation power is conferred on an agency, it may be advisable to confer a fining power as well. This reduces the pressure on the agency to use the revocation power in marginal cases." L. JAFFE 114.

91. Cf. Carrington, Civilizing University Discipline, 69 MrcH. L. Rev. 393, 40910 (1971). 
in primarily compensatory penalties are consistent with the normal mechanisms of the civil law. ${ }^{92}$ Though normally associated with the criminal sanction, deterrence is certainly not unknown to the civil law's arsenal of remedies. Not only does compensation itself typically contain a punitive aspect, ${ }^{93}$ but both exemplary and multiple damages have been accepted as valid components of the civil law despite their essentially punitive natures. ${ }^{04}$ Where private recovery for particular conduct is typically accompanied by punitive damages, there is no reason why Congress should not take this fact into account when setting penalties for similar wrongdoing perpetrated against the government. ${ }^{95}$ In gener-

92. The leading case in this area is Helvering v. Mitchell, 303 U.S. 391 (1938) where the Court rejected arguments that a statute assessing a 50\% addition to fraudulent tax deficiencies, Revenue Act of 1928, ch. 852, § 293(b), 45 Stat. 791, was penal in nature. According to the Court, the penalty was a remedial sanction designed "primarily as a safeguard for the protection of the revenue and to reimburse the Government for the heavy expense of investigation and the loss resulting from the taxpayer's fraud." 303 U.S. at 401 . This holding clearly approves a deterrent element-the penalty is supposed to protect the revenue by providing a fear of loss that will deter tax fraud.

This interpretation of Mitchell as approving some deterrent effects in an essentially remedial statute is supported by the authority cited in support of the holding. Id. at 401 n.4. Both Bartlett v. Kane, 57 U.S. (16 How.) 263, 274 (1853), and Passavant v. United States, 148 U.S. 214, 221 (1893), approve the imposition of additional duties for undervaluation of imports in an effort to discourage attempts to "escape the legal rates of duty."

The size of the penalty provided in Mitchell also supports this position. See note 86 supra. It has been pointed out that such a large penalty is unrelated to investigative expenses and losses. Gellhorn, supra note 49, at 273-74 n.21; H. GoLDschmid 914-15. That interpretation is borne out by comparing the $50 \%$ penalty still imposed for willful violations, INT. REv. CODE of 1954, $\S 6653(\mathrm{~b})$, with the penalty now allowed for negligent tax evasion. Id, §6653(a).

93. Requiring any wrongdoer to compensate his victim will, in a sense, punish the wrongdoer. It is the nature of the action as a whole that determines whether it is remedial or penal. See Brady v. Daly, 175 U.S. 148, 155-58 (1899).

94. Although it is clear that their purpose is to punish wrongdoers and to deter wrongful conduct, punitive damages are au established element of the law of torts. Scott v. Donald, 165 U.S. 58, 86-90 (1897); Day v. Woodworth, 54 U.S. (13 How.) 363, 371 (1851). See generally D. DoBBS, supra note 83, § 3.9; W. Prosser, supra note 62, § 2 .

Multiple damages have also been accepted despite their severity. Hawaii v. Standard Oil Co. of California, 405 U.S. 251, 262 (1972) (antitrust violations); United States ex rel. Marcus v. Hess, 317 U.S. 537, 550-51 (1943) (penalty for collusive bidding for government contracts). Such measures of damages have been justified as a necessary incentive for private parties to serve as "private attorneys general," 405 U.S. at 262, and it has been stressed that they are proportionally related to the amount of actual injury. 317 U.S. at 550.

Attorneys' fees are also awarded with certain civil fimes to encourage the injured parties to bring their action despite the high costs of litigation. See, e.g., Civil Rights Act of 1964, 42 U.S.C. $\$ 2000 \mathrm{e}-5(\mathrm{k})(1970)$. For cases approving the award of attorneys' fees, see United States ex rel. Marcus v. Hess, 317 U.S. 537, 550-51 (1943); Atchison, T. \& S.F. R.R. v. Matthews, 174 U.S. 96 (1899); Annot., 16 A.L.R. FED. 643 (1973).

95. This justifies, for example, the high penalties the Court has approved for willful 
al, criminal procedure will be required only when a penalty becomes so punitive that its primary purpose can no longer be characterized as compensatory. ${ }^{96}$

\section{Regulatory Sanctions}

Sanctions which fulfill a legitimate regulatory function may also be sustained against constitutional objections even where highly punitive effects are apparent. In Telephone News System, Inc. v. Illinois Bell Telephone Co., ${ }^{97}$ a three-judge district court upheld a statute which required termination of telephone service upon the request of any law enforcement agency which had determined that the phones were being used to communicate, illegal gambling information. ${ }^{98}$ Despite its acknowledgement that termination of phone service was tantamount to sentencing a business to death, ${ }^{\text {99 }}$ the district court rejected a sixth amendment challenge on the basis of conclusive evidence that the sanction was designed not to punish but to suppress the evil that was the object of the regulatory scheme. ${ }^{100}$ In the court's view, any loss to the plaintiff was merely "imcidental to the suppression of the busmess of wagering that was the intent of the statute."101

The rationale of Telephone News System suggests that, in order for the civil law to retain its essentially nonpunitive character, its use as a

tax evasion, e.g., Helvering v. Mitchell, 303 U.S. 391 (1938), collusion with intent to defraud the Government of the United States, e.g. United States ex rel. Marcus v. Hess, 317 U.S. 537 (1943), and fraudulent undervaluation of imports, e.g. Passavant v. United States, 148 U.S. 214 (1893). Successful actions for fraud typically include exemplary damages. See W. Prosser, supra note $70, \S 110$ at 736.

96. See, e.g., United States v. LaFranca, 282 U.S. 568 (1931); Helwig v. United States, 188 U.S. 605 (1903); United States v. Futura, Inc., 339 F. Supp. 162 (N.D. Fla. 1972).

97. 220 F. Supp. 621 (N.D. Ill. 1963) (three-judge court), aff'd per curiam, 376 U.S. 782 (1964).

98. 18 U.S.C. $\$ 1084$ (d) (1970).

99. 220 F. Supp. at $641-43$ (Will, J., concurring).

100. Id. at 626-27,631. According to the court:

The first matter to be consulted, legislative history, in no way suggests that Congress meant for discontinuation of telephone service to be a penalty for violation of a criminal law. To the contrary, we have already shown that the congressional aim in enacting this provision was to curtail professional gambling activities-particularly bookmaking-by depriving those engaged in such activities of the rapid wire communications facilities necessary to their operation. Id. at 630 .

101. Id. at 631. Other courts have been unable to find such regulatory purposes in money penalties. United States v. LeBeouf Bros. Towing Co., 377 F. Supp. 558, 563-65 (E.D. La. 1974) ("The Court cannot find any legitimate governmental purpose served by paragraph 5 [Federal Water Pollution Control Act, 33 U.S.C. $\$ 1161$ (b)(5)] save to reprimand the wrongdoer, by providing a pecuniary punishment, and, to deter others from illicitly discharging oil into the waterways"); United States v. Futura, Inc., 339 F. Supp. 162, 165-66 (N.D. Fla. 1972) (Economic Stabilization Act of 1970). 
vehicle for imposing noncompensatory fines should be limited to sanctions that are in fact remedial-sanctions that are aimed at securing compliance rather than punishing offenders. This distinction has long been recognized. In 1943, Professor Edmund Schwenk emphasized that "the chief interest of . . . administrative law is directed toward compliance with administrative duties . . . rather than punishment for their violation . . ."102 For Schwenk, this purpose suggested that administrative sanctions were appropriate only if they would lead to perfornance of administratively mandated duties. ${ }^{103}$ Money sanctions, then, may be used when other ineans of indirect compulsion are unavailable. ${ }^{104}$

The better reasoned cases have recognized this distinction and have stressed that the label which Congress attaches to a sanction is of little weight for purposes of the Mendoza-Martinez test. Rather than simply noting that the penalty at issue carries a civil label as soine courts have done, ${ }^{105}$ cases following the guidelimes of Mendoza-Martinez-liave carefully investigated the purpose underlying the sanction to determine whether its designation as civil is appropriate under the Constitution. ${ }^{106}$

102. Schwenk, The Administrative Crime, Its Creation and Punishment by Administrative Agencies, 42 Micr. L. REv. 51, 86 (1943).

103. Id.

104. Id. More recently, a similar approach has been advocated by Professor Jonathan Charney, who suggests that an uncompensated loss is not a criminal sanction if it is "a reasonable, necessary, and incidental effect of government action." Charney, supra note 47 , at 511; see id. at 510-12, 514-16. Charney, however, refuses to accept that money penalties can ever serve a remedial function. Id. n.162. The position taken in this Comment falls in between the opposing stances taken by Professors Charney and Goldschmid. Goldschmid believes that civil money penalties are appropriate if they "may be expected to have a prophylactic or remedial effect." H. GoLDschMID 914. Charney, on the other hand, contends that a money penalty can never have either. This Comment follows the line of reasoning suggested by Schwenk, supra note 102. The only prophylactic effect a money sanction could have is through pure deterrence, marking it as penal in nature. It can, however, serve as a means of indirect compulsion where no other means of obtaining compliance is possible, and may in this sense have a legitimate remedial effect. Id.

105. See, e.g., Beall Const. Co. v. OSHRC, 507 F.2d 1041, 1044 (8th Cir. 1974); American Sinelting \& Ref. Co. v. OSHRC, 501 F.2d 504, 515 (8th Cir. 1974) ("Congress here clearly intended to create a civil sanction"); United States v. J.B. Williams Co., 498 F.2d 414, 421 (2d Cir. 1974).

106. See, e.g., United States v. LeBeouf Bros. Towing Co., 377 F. Supp. 558, 562 (E.D. La. 1974); United States v. Futura, Inc., 339 F. Supp. 162, 165 (N.D. Fla. 1972); Telephone News System, Inc. v. Illinois Bell Tel. Co., 220 F. Supp. 621, 629-32 (N.D. Ill. 1963) (three-judge court), aff'd per curiam, 376 U.S. 782 (1964).

A federal district court strongly emphasized the proper focus of the MendozaMartinez inquiry in United States v, LeBeouf Bros. Towing Co., 377 F. Supp. 558, 563 (E.D. La. 1974):

At first blush, the paragraph here in question appears to be nonpenal, es- 
These courts have been careful to focus on the sanction involved and have not been deterred by a legislative history which has not provided conclusive evidence of the aim of the statute. ${ }^{107}$

The proper analysis of legislative purpose is exemplified by Chief Justice Warren's pre-Mendoza opinion in Trop $v$. Dulles. ${ }^{108}$ Trop was contesting a statute which provided for expatriation upon courtmartial conviction of desertion in time of war. The Court had to address the issue of whether the sanction was penal in nature to determine whether the eighth amendment's proscription of cruel and unusual punishment was applicable. The government contended that the statute, rather than being penal, was a regulatory provision authorized by the war power. ${ }^{109}$ The Court rejected this contention. Allowing that regulation of deserters was among Congress' powers, the Court held that "a statute prescribing the consequence that will befall one who fails to abide by these regulatory provisions is a penal law." 110 As a concurring Justice explained:

It is difficult, indeed, to see how expatriation of the deserter helps wage war except as it performs that function when imposed as punishment. It is obvious that expatriation cannot in any wise avoid the harm apprehended by Congress. After the act of desertion, only punishment can follow, for the harm has been done. ${ }^{111}$

While Mendoza-Martinez clearly establishes the appropriate inquiry for determining whether a particular sanction is of such a punitive nature as to require the procedural protections of the criminal law, the courts have shown some reluctance to apply its analysis to statutory

pecially in view of the purported "civil penalty" that is assessed for the proscribed activity. But to be guided in the interpretive process by such superficial implements as word classification or legal jargon truly would be an analytical pitfall in allowing form to replace substance. Chief Justice Warren, speaking for the Court in Trop v. Dulles, 356 U.S. 86, 94 . . (1958) recognized the patent inadequacy of such an approach when he remarked: "How simple would be the tasks of constitutional adjudication and of law generally if specific probleins could be solved by inspection of labels pasted on them!" The real nature and intended objective of a statute must be unearthed to avoid Swiftonian-like deceit. [footnotes omitted].

107. See, e.g., United States v. LeBeouf Bros. Towing Co., 377 F. Supp. 558 (E.D. La. 1974); United States v. Futura, Inc., 339 F. Supp. 162 (N.D. Fla. 1972); cf. United States v. Krapf, 180 F. Supp. 886 (D.N.J. 1960), aff'd, 285 F.2d 647 (3d Cir. 1961). Though its reasoning led it to a conclusion different from that of this Comment, the Fifth Circuit was sinilarly diligent in its analysis of OSHA. Sce Atlas Roofing 9991012. Compare id, with Irey I 1286-87 and American Sinelting \& Ref. Co. v. OSHRC, 501 F.2d 504, 515 (8th Cir. 1974).

108. 356 U.S. 86 (1958).

109. Id. at 97.

110. $I d$.

111. Id. at 109-10 (Brennan, J., concurring). 
money penalties. ${ }^{112}$ In general, the courts have felt constrained ${ }^{113}$ by an early line of cases ${ }^{114}$ which appeared to grant Congress broad discretion to einploy civil fines to enforce its legislative policies. ${ }^{115}$ It seems, however, that such precedents should be controlling only in areas such as revenue raismg and foreign relations where the Court has traditionally deferred to the competence of its coequal branches of government. ${ }^{110}$

112. See, e.g., Irey I 1203-06; United States v. J.B. Williams Co., 498 F.2d 414, 421 (2d Cir. 1974). Only recently have the courts begun to scrutinize civil fines. See, e.g., United States v. LeBeouf Bros. Towing Co., 377 F. Supp. 558 (E.D. La. 1974) (applying sixth amendment to a "civil" money sanction); United States v. Futura, Inc., 339 F. Supp. 162 (N.D. Fla. 1972) (applying criminal protections to a federal sanction intended to be civil); Tulsa Ready Mix Concrete Co. v. McMichael Concrete Co., 495 P.2d 1279 (Okla. 1972). This more recent view, rigorously applying the Mendoza-Martinez test, has been widely accepted by the commentators. See, e.g., McClintock \& Bohrnsen, Constitutional Challenges, 10 GonZAGA L. REv. 361, 385-88 (1974); Comment, supra note 20, at 230-31; Comment, supra note 47, at 355-57.

113. In examining OSHA, the Third Circuit openly questioned the wisdom of the administrative imposition scheme before it, but felt that its holding was compelled by the present state of the law. See Irey I 1205 n.11; Irey II 1207, 1219. Similarly, the Second Circuit felt compelled to reject a request for a sixth amendment jury in FTC enforcement proceedings since "[i]n the face of a long line of contrary authority, appellants [had] not dirccted [the court's] attention to any civil penalty provision that had been held sufficiently criminal in nature to invoke the protections of the Sixth Amendment." United States v. J.B. Williams Co., 498 F.2d 414, 421 (2d Cir. 1974). This aspect of the decision has been criticized, see Note, supra note 46, at 523-25, and at least one recent decision has applied the sixth amendment to a case of this type, see United States v. LeBeouf Bros. Towing Co., 377 F. Supp. 558 (E.D. La. 1974); cf. United States v. Futura, Inc., 339 F. Supp. 162 (N.D. Fla. 1972).

114. Elting v. N. German Lloyd, 287 U.S. 324 (1932); Lloyd Sabaudo S.A. v. Elting, 287 U.S. 329 (1932); Oceanic Steam Navigation Co. v. Stranahan, 214 U.S. 320 (1909); Hepner v. United States, 213 U.S. 103 (1909).

115. E.g., Irey I 1204; Atlas Roofing 1002; United States v. J.B. Williams, 498 F.2d 414 (2d Cir. 1974); see H. GoLdschmID 915-16; Comment, The Concept of Punitive Legislation and the Sixth Amendment: A New Look at Kennedy v. Mendoza-Martinez, 32 U. CHI. L. Rev. 290, 292-93 (1965).

116. Cf. Note, supra note 30 , at 548-49. Issues relating to foreign relations have traditionally been avoided by the Court; it is acutely aware of the lack of judicial standards for approaching such problems and the importance of maintaining imternal unity on such matters. See Baker v. Carr, 369 U.S. 186, 211-13 (1962); cf. Oetjen v. Central Leather Co., 246 U.S. 297, 302 (1918); Foster v. Neilson, 27 U.S. (2 Pet.) 253, 307 (1829). Both tariff and immigration policies carry broad international implications. As a result, the Court has been careful to preserve room for executive and legislative discretion in designing tariff policies, see J.W. Hampton, Jr. \& Co. v. United States, 276 U.S. 394 (1928) (approves statutory provisions for flexible tariffs); Bartlett v. Kane, 57 U.S. (16 How.) 263 (1853) (congressional discretion in designimg methods of enforcing tariffs), and the States have been expressly denied the authority to lay duties on imports or exports without the consent of Congress. U.S. ConsT. art. I, $\$ 10, \mathrm{cl} .2$; Board of Trustees v. United States, 289 U.S. 48, 56-57 (1933).

Similarly, Congress' power to exclude aliens and regulate naturalization and immigration, U.S. CoNST. art. I, \& 8, cl. 4, has been vigorously preserved, Fung Yue Ting 


\section{The Exclusive Power Doctrine}

Analysis of the leading case of Oceanic Steam Navigation Co. v. Stranahan ${ }^{117}$ supports this interpretation. Stranahan concerned a challenge to the validity of legislation authorizing the Secretary of Commerce and Labor to impose a $\$ 100$ fime on a vessel's owner for each immigrant brought into the Umited States with a "Ioathsome or contagious disease" that could have been detected by a proper medical exammiation at the time of embarkation. ${ }^{118}$ The Secretary (or his agent) was empowered to impose the fixed penalty on the strength of his own administrative findings of fact. Relying chiefly on cases which had sustained the power of Congress to grant customs officials authority to impose money penalties for undervaluation of imported goods, ${ }^{119}$ the Supreme Court approved this procedure while presenting a broad conception of congressional power:

[I]t [is] within the competency of Congress, when legislating as to matters exclusively withim its control, to impose appropriate obligations and sanction their enforcement by reasonable money penalties, giving to executive officers the power to enforce such penalties without the necessity of involving the judicial power. ${ }^{120}$

v. United States, 149 U.S. 698, 705 (1893); Chinese Exclusion Case, 130 U.S. 581, 60304 (1889), and a strong line of authority attests to the exclusivity of this particular power. Graham v. Richardson, 403 U.S. 365, 376-79 (1971); Truax v. Raich, 239 U.S. 33, 42 (1915); United States v. Wong Kim Ark, 169 U.S. 649, 700-01 (1898); Chirac v. Chirac, 15 U.S. (2 Wheat.) 259, 269 (1817). "[The states] can neither add to nor take from the conditions lawfully imposed by Congress upon admission, naturalization, and residence of aliens in the United States or the several states." Takahashi v. Fish \& Game Comm'n, 334 U.S. 410, 419 (1948). See notes 133-34 infra and accoinpanying text.

Similar scope may also be found in the power to raise revenue where federal taxes are preemptive in scope. See, e.g., Helvering v. Mitchell, 303 U.S. 391 (1938); cf. Note, supra note 30, at 548. See generally Library of CONGRess, THE CONSTitution of tHe UNITED STATES OF AMERICA: ANALYSIS AND INTERPRETATION 133-34 (1973).

117. 214 U.S. 320 (1909).

118. An Act to regulate the immigration of aliens into the United States, ch. 1012, $\S 9$, 32 Stat. 1213, 1215-16 (1903), cited in Oceanic Steam Navigation Co. v. Stranahan, 214 U.S. 320, 331-32 (1909). Similar statutes in this area are still enforced by the Attorney General through the Immigration and Naturalization Service subject to only limited judicial review. 8 U.S.C. $\$ \$ 1221$ (d), 1227(a), 1229, 1253(c)-(f), 1281(d), 1284-87, 1321, 1322, 1333 (1970); see Elting v. N. German Lloyd, 287 U.S. 324, 328 (1932); H. GoLDschmm 960.

119. See 214 U.S. at 338-39, citing Passavant v. United States, 148 U.S. 214 (1893); Bartlett v. Kane, 57 U.S. (16 How.) 263 (1853).

120. 214 U.S. at 339; see Lloyd Sabaudo S.A. v. Elting, 287 U.S. 329, 334 (1932). The Court suggested that taxation and tariff were subject to this exclusive control. 214 U.S. at 334. Then, in upholding the legislation at issue, it explained:

As the authority of Congress over the right to bring aliens into the United States enibraces every conceivable aspect of that subject, it must follow that if Congress has deemed necessary to impose particular restrictions on the com- 
On first reading, the broad language of Stranahan seems to disclose no limit on Congress' authority to enact administrative procedures for imposing civil money penalties. A closer reading, however, suggests that the actual bounds set forth in the opinion are much narrower than its broad language seems to imply. First, Stranahan is expressly limited to inatters "exclusively in the control of Congress." is to have any ineaning, it inust refer to those few powers, such as taxation, tariffs, and regulation of immigration and naturalization, which can be exercised only by the federal government. ${ }^{122}$ Even where Congress has such exclusive control over an area, Stranahan directs the courts to examine "the constitutional right of Congress to enact such legislation." ${ }^{123}$ Civil procedure is incompatible with the constitutional rights guaranteed the criminal defendant, ${ }^{124}$ and Congress obviously has no authority to legislate a procedure that is incompatible with the Constitution. ${ }^{125}$ Hence, if the courts examine a sanction and determine that its primary purpose is pumitive, the provision is invalid unless appropriate protections are available.

This approach is evident in the several decisions in which the Supreme Court has struck down a variety of purportedly civil sanctions as penal in nature. Despite the suggestion in Stranahan that Congress would have broad authority to enforce its tax and tariff policies through the civil law, ${ }^{120}$ several such provisions have been found so penal in

ing in of aliens, and to sanction such prohibitions by penalties enforcible by administrative authority; it follows that the constitutional right of Congress to enact such legislation is the sole measure by which its validity is to be determined by the courts. Id. at 340 .

121. 214 U.S. at 339.

122. See id.; cf. Note, supra note 30, at 548-49. Much of the confusion concerning the scope of Stranahan is a result of the conflicting language contained in Lloyd Sabaudo S.A. v. Elting, 287 U.S. 329 (1932), where the Supreme Court describes Congress' control over the admission of aliens once as "exclusive," id. at 334, and once as "plenary," id. at 335. As Professors Davis and Jaffe have each pointed out, if the Court's suggestion that Congress may create civil money penalties is taken seriously, congressional authority to permit administrative imposition of money penalties is boundless because of the plenary power to regulate commerce. K. DAvis $\$ 2.13$; L. JAFFE 111. Surely, although regulation of federal banks is in the national interest and within the power granted to Congress under the commerce clause, the Court would not allow administrative imposition of fines upon thieves whom an administrative law judge has found guilty of robbing federal banks. See cases cited at note 50 supra. Stranahan is clearly concerned with "exclusive," 214 U.S. at 339, or "absolute" congressional authority, id. at 342, and Elting makes no pretense of expanding that precedent, see 287 U.S. at 334-35.

123. 214 U.S. at 340.

124. Helvering v. Mitchell, 303 U.S. 391, 402 (1938).

125. See id. at 402 n.6; Comment, supra note 115, at 303; cf. Wing Wong v. United States, 163 U.S. 228 (1896) (striking down administrative sanction of incarceration). 126. 214 U.S. at 334 . See note 120 supra. 
nature that constitutional protections normally reserved for the criminally accused were required. ${ }^{127}$ Punitive tax measures have been held to be outside the power to raise revenue, ${ }^{128}$ and Congress' power to impose civil money penalties has been limited to fines that are neither unreasonable nor confiscatory. ${ }^{129}$ More recently, the Court has used the prinary nature test in applying the sixth amendment to laws enacted under the war power ${ }^{130}$ and in extending the right to trial by jury to criminal contempt proceedings. ${ }^{131}$ Such results indicate that the precedential value of early cases which espoused judicial deference to legislative labels and historic traditions nay be severely limited. ${ }^{132}$

\section{Application of the Mendoza-Martinez Test: The OSHA Example}

It is very doubtful whether reliance should be placed on the broad language of Stranahan in matters other than those, like immigration and tariffs, over which Congress has such coinplete control that the courts have traditionally deferred to legislative judgments. ${ }^{133}$ The commerce power under which OSHA was promulgated is peculiarly non-exclu-

127. United States v. LaFranca, 282 U.S. 568 (1931) (double jeopardy and prohibition tax); Lipke v. Lederer, 259 U.S. 557 (1922) (constitutional hearing required to impose tax that was penal in nature); Helwig v. United States, 188 U.S. 605 (1903) (constitutional hearing required to impose additional dnties when appraised value of imported goods exceeds value declared at customs); see United States v. Constantine, 296 U.S. 287 (1935) (federal tax imposed for violation of state law was penal and, thus, an unconstitutional intrusion on the state police power).

128. United States v. Constantine, 296 U.S. 287 (1935); United States v. LaFranca, 282 U.S. 568 (1931); Lipke v. Lederer, 259 U.S. 557 (1922); Bailey v. Drexel Furniture Co., 259 U.S. 20 (1922).

129. Rex Trailer Co. v. United States, 350 U.S. 148, 154 (1956); United States v. Constantine, 296 U.S. 287, 295 (1935); Helwig v. United States, 188 U.S. 605, 610-12 (1903); see One Lot Emerald Cut Stones and One Ring v. United States, 409 U.S. 232, 237 (1972); Lloyd Sabaudo S.A. v. Elting, 287 U.S. 324 (1932).

130. Kennedy v. Mendoza-Martinez, 372 U.S. 144 (1963); Trop v. Dulles, 356 U.S. 86 (1958).

131. Bloom v. Illinois, 391 U.S. 194 (1968). Bloom reversed a long line of cases in which the Supreme Court had held that criminal contempt proceedings were outside the trial-by-jury provisions of the sixth amendment, e.g., Green v. United States, 356 U.S. 165 (1958). Bloom's dramatic reversal of estabhished precedent was the result of a reexamination of criminal contempt which led the Court to conclude "that serious contempts are so nearly like other serious crimes that they are subject to the jury trial provisions of the Constitution . . ." 391 U.S. at 198. See generally R. PERKINs, supra note 70 , at 534 .

132. See Comment, supra note 47, at 354, 356-57, 359-60; Comment, The Availability of Criminal Jury Trials Under the Sixth Amendment, 32 U. Crr. L. REv. 311, 323 (1965).

133. See notes 117-132 supra and accompanying text. See Comment, supra note 47, at 355 n.76; Note, supra note 30, at 548-49. But see Irey I 1203; United States v. J.B. Williams Co., 498 F.2d 414, 421 (2d Cir. 1974). See also Atlas Roofing 1011. 
sive. ${ }^{134}$ Indeed, OSHA itself contains specific provisions to encourage state action designed to facilitate occupational safety. ${ }^{195}$ Hence, OSHA's penalty provisions should not be sustained merely by reference to Congress' broad discretion to design methods to enforce its legislative policies. ${ }^{130}$

Likewise, the legislative history of OSHA does not provide the conclusive evidence required to end the sixth annendment inquiry. ${ }^{137}$ Committee hearings and reports suggest that there was substantial dispute over the severity and intent of the Act's sanctions; ;38 however, since discussion of these provisions was apparently reserved for executive session, ${ }^{130}$ the purpose of the sanctions remains unclear. ${ }^{140}$

134. "[F]ederal regulation of a field of commerce should not be deemed preemptive of state regulatory power in the absence of persuasive reasons . . . ." Florida Lime \& Avocado Growers, Inc. v. Paul, 373 U.S. 132, 142 (1963); cf. Breard v. City of Alexandria, 341 U.S. 622, 634 (1951) ("[T]here necessarily remains to the States, until Congress acts, a wide range for the permissible exercise of power appropriate to their territorial jurisdiction although interstate commerce may be affected .... States are thus enabled to deal with local exigencies and to exert in the absence of conflict with federal legislation an essential protective power"); Kellyn v. Washington, 302 U.S. 1, 910 (1937).

135. OSHA, 29 U.S.C. $\S 667$ (1970).

136. See Atlas Roofing 1000, 1011. Contra, Irey I 1204-05. The analysis in Irey $I$ is criticized at note 141 infra.

137. Counment, supra note 20, at 440; Note, OSHA Penalties: Some Constitutional Considerations, 10 Iрино L. Rev. 223, 233 (1974). See Atlas Roofing 1000; notes 13839 infra and accompanying text. But see Irey $I$ 1205; Beall Const. Co. v. OSHRC, 507 F.2d 1041, 1044 (8th Cir. 1974); American Smeltiug \& Ref. Co. v. OSHRC, 501 F.2d 504,515 (8th Cir. 1974). The last three cases cited contain superficial analyses of congressional intent.

138. See, e.g., Hearings on S. 2193 and S. 2788 Before the Subcomm. on Labor of the Senate Comm. on Labor and Public Welfare, pt. 1, 91st Cong., 1st Sess. 87-89 (1970) (testimony of Secretary of Labor Shultz and Solicitor Silberman); id. at 684 (testimony of Mr. Sheehan, Legislative Director of the United Steelworkers); Hearings on H.R. 843, H.R. 3809, H.R. 4294, and H.R. 13373 Before the Select Subcomm. on Labor of the House Comm. on Education and Labor, pt. 1, 91st Cong.; 1st Sess. 135-38 (1969) (testimony of Secretary of Labor Shultz aud Solicitor Silberman); id. at 101012 (comments of Rep. O'Hara); cf. H.R. REP. No. 91-1291, 91st Cong., 2d Sess. 53, $55,59-60$ (1970) (minority report). 136.

139. Hearings (Senate), supra note 138, at 88; Hearings (House), supra note 138, at

140. See Atlas Roofing 1000. While remarks by at least one member of Congress clearly indicated a desire to use civil sauctions to make certain that offenders were punished, Remarks of Senator Dommick, supra note 51, floor debate on this issue was noticeably absent. Atlas Roofing 1000 . OSHA's legislative history is strikingly bare compared to the legislative histories of other statutes where the courts have been able to find conclusive evidence of remedial or penal intent. See, e.g., Kennedy v. MendozaMartinez, 372 U.S. 144, 170-84 (1963), where the Court traced the provisions in question back to 1865 and found in each segment of the legislative history a reaffirmation of congressional intent to employ its power over citizenship to punish draft evaders. 
Mendoza-Martinez requires an objective assessment of OSHA's penalty provisions. ${ }^{141}$ The Supreme Court has suggested several factors which might be useful in such an assessment:

Whether the sanction involves an affirmative disability or restraint, whether it has historically been regarded as a punishment, whether it comes into play only on a finding of scienter, whether its operation will promote the traditional aims of punishment-retribution and deterrance, whether the behavior to which it applies is already a crime, whether an alternative purpose to which it may rationally be connected is assignable for it, and whether it appears excessive in relation to the alternative purpose assigned $\ldots . .^{142}$

When the OSHA penalty provisions are analyzed using these factors, serious questions arise as to their constitutionality. ${ }^{143}$

First, while money penalties do not fit the traditional definition of an affirmative disability as a legal incapacity, ${ }^{144}$ such sanctions have been properly held to constitute a restraint. ${ }^{145}$ Although they do not destroy the legal capacity to pursue any particular course of action (unless, of course, a business is driven into bankruptcy by the penal-

141. Atlas Roofing 1000. Contra, Irey $I$ 1205. Aside from its misplaced reliance on Stranahan, compare Irey I 1204 with notes 112-36 supra and accompanying text, the Third Circuit panel's decision in Irey is objectionable because of its misunderstanding of the mandate of cases like Mendoza-Martinez which require the courts to look behind the label attached by Congress to determine conclusively the actual congressional purpose in providing a sanction. See notes 105-116 supra and accompanying text. Although it gives lip service to the principle that "the label attached by Congress does not preclude judicial review of a statute which transgresses a constitutional right," Irey $l 1204$, the court provides no hint of how to determine when a constitutional right has been transgressed. It merely accepts the legislative label. See id. at n.9.

142. Kennedy v. Mendoza-Martinez, 372 U.S. 144, 168-69 (1963) (citations omitted). It should be emphasized that these factors will rarely all point in the same direction, id. at 169; Atlas Roofing 1010-11, and that the list is not exhaustive.

143. McClintock \& Bohrnsen, supra note 112, at 382-93; Comment, supra note 20 , at 437-44; Note, supra note 137, at 228-34. Contra, Irey I 1204; Atlas Roofing 999-1002, 1009-12. While the Fifth Circuit's opinion in Atlas Roofing went beyond that of the panel decision in Irey, see note 141 supra, by recognizing that neither legislative history nor legislative classification provided the conclusive evidence necessary to establish the constitutional purpose of OSHA's penalty provisions, compare Atlas Roofing 1000 with lrey I 1204-05, the decision is only slightly more instructive since the court confined itself to a superficial inquiry, according deference to congressional expertise each time the Mendoza analysis required an investigation of the actual purpose in providing the penalties. See notes 149,173 infra and accompanying text.

144. Atlas Roofing 1001.

145. Id.; United States v. LeBeouf Bros. Towing Co., 377 F. Supp. 558, 564 (E.D. La. 1974); United States v. Futura, Inc., 339 F. Supp. 162, 165 (N.D. Fla. 1972); cf. United States v. Krapf, 180 F. Supp. 886, 887-90 (D.N.J. 1960), aff'd, 285 F.2d 647 (3d Cir. 1961). 
ty), inoney penalties obviously restrain a business from pursuing its goals by diminishing its resources. ${ }^{146}$ This conclusion applies to all of OSHA's money penalty provisions, ${ }^{147}$ simce courts liave traditionally attached little significance to the severity of a penalty in determining whether it imposes disabilities or restraints. ${ }^{148}$

Second, it is difficult to escape the conclusion that the kinds of noney penalties established in OSHA have historically been considered penal. ${ }^{140}$ Money fines are coininonly employed by the criminal law as an alternative to incarceration and continue to be regarded as a form of punishment. ${ }^{150}$ While it is true that monetary sanctions have been accepted by the civil law where Congress' discretionary authority is deemed absolute, ${ }^{151}$ such civil fines have otherwise normally been rejected unless they have a legitimate remedial purpose. ${ }^{152}$ The recipient of OSHA penalty proceeds, the Government, ${ }^{153}$ is obviously uninjured by an OSHA violation. Violations under the Act may harm an einployee, but the only injury to the Government is the affront to its role as sovereign. It is precisely this sort of wrong that has traditionally been redressed by the penal sanction. ${ }^{154}$

With respect to scienter, OSHA distinguishes between two types of knowledge in determining the appropriate penalty for a particular violation. Imposition of the Act's inaximuin penalty of $\$ 10,000$ for willful

146. But see Telephone News Sys., Inc. v. Illinois Bell Tel. Co., 220 F. Supp. 621 (N.D. III. 1963), discussed at notes 98-101 supra and accompanying text.

147. Atlas Roofing 1000; McClintock \& Bohrnsen, supra note 112, at 388-89; Comment, supra note 20, at 440-41.

148. Flemming v. Nestor, 363 U.S. 603, 614, 616 n.9 (1960).

149. See McClintock \& Bohrnsen, supra note 112, at 389; Comment, supra note 20, at 441; Note, supra note 137, at 231-32. But see Atlas Roofing 1001. The suggestion by the Fifth Circuit that the historical factor is inconclusive because civil penalties have been accepted where they serve a remedial function is indicative of the court's refusal to follow the thrnst of the Mendoza-Martinez inquiry. The whole purpose of the MendozaMartinez analysis is to determine whether a legitimate remedial purpose can be rationally assigned to the sanction at issue. See notes 77-111 supra and accompanying text. While Atlas Roofing is correct in pointing out that remedial money penalties have historically not been considered punishment, this is irrelevant unless such an effect can be attributed to the OSHA sanctions.

150. Money fines were used as a form of punishment long before incarceration, which is a relatively new penal sanction. N. KITTRIE, THE RIGHT To BE Different: Deviance ANd ENForced Therapy 16-17 (1971). Modern statutes commonly provide for fines as an alternative to imprisoninent. Atlas Roofing 1001.

151. See notes 112-32 supra and accompanying text.

152. See notes 74-81 and 97-111 supra and accompanying text.

153. OSHA, 29 U.S.C. $\$ 666(\mathrm{k})$ (1970).

154. Sec Comment, The Occupational Safety and Health Act of 1970: Its Role in Civil Litigation, 28 Sw. L.J. 999, 1005 (1974); note 69 supra and accompanying text. See also Note, supra note 137, at 232. 
violations ${ }^{155}$ requires a showing of actual knowledge or reckless disregard of the prohibited conduct. ${ }^{156}$ Actions to impose penalties for serious $^{157}$ and non-serious violations ${ }^{158}$ are vulnerable to the tort-type defense that the exercise of reasonable care would not have made the violation apparent to the employer. ${ }^{159}$ None of OSHA's provisions imposes strict liability. ${ }^{180}$

The requirements for imposing the sanction for willful violations are identical to the conventional scienter element of a crime. To prove a willful violation, the government has the burden of establishing deliberate defiance or reckless disregard of the Act, ${ }^{161}$ much as it has the burden of establishing criminal intent as an element of more traditional crimes. ${ }^{162}$ This factor weighs heavily against the argument that the sanction for willful violations is remedial. ${ }^{163}$

The highly punitive nature of OSHA's civil penalty for willful violations is particularly clear when its relationship to the Act's criminal sanctions is considered. Where a willful violation causes an employee's death, OSHA authorizes the institution of formal criminal proceedings. ${ }^{164}$ Willful violations can, however, also be handled administratively under section $666(\mathrm{a})$, whether or not the alleged violation results in a fatality. ${ }^{105}$ It is obvious that a finding of "willfulness" is

155. OSHA, 29 U.S.C. $\$ 666(a)(1970)$.

156. Irey I 1206-07.

157. OSHA, 29 U.S.C. $\$ 666(b)$ (1970).

158. Id. $\S 666(\mathrm{c})$.

159. Brennan v. OSHRC, 511 F.2d 1139 (9th Cir. 1975) (both serious and nonserious violations held to require knowledge).

160. See id.; Atlas Roofing 1001. But see Comment, supra note 20, at 441-42.

161. Irey I 1207.

162. See generally R. PeRkins, supra note 70, at 743-47.

163. Cf. Irey $I$ at 1204. But see Atlas Roofing 1001-02. The Fifth Circuit's careful refusal to set forth a view on the nature of willful violations was an implicit recognition of the importance of the scienter issue in identifying penal sanctions. See id. at 1002 n.39. While nonwillful violations do not satisfy this test, it should be noted that the scienter element is not always necessary to classify a sanction as penal. See, e.g., Helwig v. United States, 188 U.S. 605, 610-12 (1903) (two penalties for identical conduct, one with and one without scienter, both held penal). See also McClintock \& Bohrnsen, supra note 112, at 389 .

164. OSHA, 29 U.S.C. $\$ 666(\mathrm{e})(1970)$.

165. See id. \$ 666(a); Atlas Roofing 1009. It should be noted that the objection presented here is not to the retributive effects of the criminal penalties which provide incarceration for behavior that could be punished only by a fine had a death not resulted. This objection, which has been raised by other commentators, see, e.g., McClintock \& Bohrnsen, supra note 112, at 390; Comment, supra note 20 , at 442 , was properly rejected by the Fifth Circuit in its consideration of OSHA, Atlas Roofing 1002 n.41. The problem is not that different harms can result in different penalties, but that 
more likely under civil law standards of proof than when a jury is required to reach that conclusion beyond a reasonable doubt. ${ }^{106}$ In fact, a busimess may be better off defending a charge under the criminal section so that constitutional protections would be clearly available. ${ }^{\mathbf{1 6 z}}$ Since they are not subject to imprisonment, ${ }^{168}$ corporate defendants have no greater vulnerability under the criminal law than they do under civil sanctions. They are faced with the same punishment in both instances, but are deprived of important procedural protections in the civil context. ${ }^{169}$

Moreover, much of the behavior made punishable under OSHA is already a crime $m$ that it is punishable under criminal provisions of housing and safety codes in many cities and states. ${ }^{170}$ It is unfair to dismiss this position, as has the Fifth Circuit, as the untenable contention that the treatment of certain behavior by other governmental units limits Congress' election of sanctions. ${ }^{171}$ The Mendoza-Martinez test should function to weed out civil sanctions established to punish behavior that is already prohibited by criminal provisions which are difficult to enforce. The attitudes of other units of government are suggestive of the comnunity's attitude toward the behavior in question. Behavior which is morally condemned by the community has traditionally been viewed as falling within the provimce of the criminal law. ${ }^{172}$

Fimally, there remains the issue of whether OSHA's money sanctions can be rationally coimected to any purpose other than pumish-

the same harm can result in different penalties at the whim of the Secretary of Labor. Sec note 166 infra and accompanying text.

166. The potential for abuse in such a statutory scheme should be stressed. In Irey $I$, for example, suit was brought under $\$ 666(a)$ despite the undisputed fact that an employee had been killed as a result of the alleged violation. Irey I 1201. The issue of willfulness was contested, however, and it was undoubtedly apparent to the government that a favorable holding was more likely in an administrative proceeding where a jury would be unavailable and the standard was one of preponderance of the evidence, than in an article III court where a criminal jury would have been required to resolve the issue with reference to the more stringent "beyond-reasonable-doubt" standard. $C f$. Atlas Roofing 1002-1011.

167. Irey I 1204; Comment, supra note 20, at 443.

168. Atlas Roofing 1009; United States v. R.L. Polk \& Co., 438 F.2d 377, 379 (6th Cir. 1971).

169. Irey I 1204; Atlas Roofing 1009-10.

170. See Comment, supra note 20 , at 441 n.150. See also McClintock \& Bohrnsen, supra note 112, at 389.

171. Atlas Roofing 1010.

172. See notes 61-64 supra and accompanying text; cf. District of Coluinbia v. Clawans, 300 U.S. 617, 628 (1937). See generally W. LAFAve \& A. Scotr, HandBoox on Criminal Law 9-10 (1972); R. Perkins, supra note 70, at 11. 
ment. $^{173}$ The apparent purpose of OSHA's civil penalties supports their classification as penal. ${ }^{174}$ Indeed, it is difficult to conceive of a nonpenal purpose that is served by the sanctions provided by the Act. Penalties are assessed according to the gravity of the violation and other criteria typically considered in imposing criminal sanctions. ${ }^{175}$ The fines are imposed, after the fact, for violations which have already occurred. They do not compensate anyone for any injury resulting from the violations and do not act to remove any hazard. In short, the only purpose of the Act's penalties for willful and non-willful violations is to punish the employer for permitting a hazard to exist. ${ }^{176}$

Furthermore, retributive aims are evident, particularly in the Act's sanction for willful violations. If the goal of the Act, as the Secretary of Labor contends, is "to encourage compliance with" regulations, ${ }^{177}$ it is difficult to understand why a higher penalty is required for willful than for non-willful violations when the same threat to public safety has

173. The difficulty with the Fifth Circuit's approach in Atlas Roofing, see note 143 supra, is most apparent in its refusal to attempt to determine any purpose other than punishment that may rationally be ascribed to the OSHA penalty provisions. See Atlas Roofing 1010. According to the court, the judiciary is unqualified to examine the appropriateness of particular sanctions in achieving the purposes of the Act. Id. See also Irey I 1205. While this judicial respect for the legislative body's superior capacity to design solutions for social problems is laudable, the courts cannot avoid all scrutiny of the legislative inquiry. Congress may determine that a purely punitive civil sanction is the method best calculated for achieving a particular purpose, but that will not make the method constitutional. Trop v. Dulles, 356 U.S. 86, 95 (1958). A purpose other than punishment must be rationally ascribable to the sanction before it nuay be deemed nonpenal. Id. at 96 . In order properly to divine the nature of a sanction, the courts must look to the statute to determine the evident purpose of the legislature.

174. Authority for this approach to the statutory purpose is found in two cases in which the Court stressed that labelling cannot obscure the true intent of an act. Trop v. Dulles, 356 U.S. 86, 96 (1958) (expatriation after court-martial for desertion in time of war held to be a punishment); United States v. Constantine, 296 U.S. 287, 295 (1935) (provisions of the Revenue Act of 1926, providing for a "special income tax" of $\$ 1,000$ on retail liquor dealers acting in violation of state or muuicipal law and inposing fines and imprisonment for failure to pay the special tax, held to be a penalty which could not be converted to a tax by mere labelling).

175. Comment, supra note 20, at 442; see Atlas Roofing 1002; Note, supra note 137, at 232. In assessing penalties, the OSHRC is required by statute to give "due consideration to the appropriateness of the penalty with respect to the size of the business of the employer being charged, the gravity of the violation, the good faith of the employer, and the history of previous violations." OSHA, 29 U.S.C. $\$ 666(\mathrm{i})$ (1970). See also United States v. LeBeouf Bros. Towing Co., 377 F. Supp. 558, 564 n.11 (1974) (commenting that provisions of the Federal Water Pollution Control Act, similar to those found in OSHA, resembled criteria for criminal sentencing).

176. Cf. Trop v. Dulles, 356 U.S. 86, 109-10 (1958) (Brennan, J., concurring), quoted in text accompanying note 111 supra. Contra, Irey I 1203-06; Atlas Roofing 1011.

177. Allas Roofing 1002. 
occurred. ${ }^{178}$ Surely the extent of a hazard does not depend on whether it is the result of willful or merely negligent conduct. The effect of murder does not differ from that of manslaughter. The different penalties associated with the two crimes are merely the result of a sense that the perpetrator of one is less culpable than that of the other. Society seeks greater retribution for deeds that it senses are more wicked. ${ }^{179}$ This desire for retribution is the only credible aim of the higher penalty for willful violations.

It is possible, however, to assign a legitimate purpose to section $666(d)$ which authorizes a maximum penalty of $\$ 1000$ per day for failure to comply with an OSHRC abatement order. ${ }^{180}$ The aim of this provision differs greatly from that of OSHA's other civil penalties. The violation already exists. A penalty for non-abatement is virtually the only means available to coerce the violator to rectify the situation. The effect of such a sanction is to coerce the violator to comply with regulations, much as penalties for civil contempt are designed to coerce a party into complying with a court order. ${ }^{181}$ Rather than deterrence, the aim of section $666(d)$ is to remedy an ongoing wrong, a valid function of the civil law. ${ }^{182}$

178. Compare OSHA, 29 U.S.C. $\$ 666$ (a) (1970) (maximum penalty of $\$ 10,000$ for serjous violation), with id. $\$ \S 666(b)$-(c) (maximum penalty of $\$ 1,000$ for nonserious violations). The large size of the section 666(a) penalty also brings it into question under another criterion suggested in Mendoza-Martinez, "whether it appears excessive in relation to the alternative purpose assigned." 372 U.S. 144, 169 (1963).

179. See H. Packer, The Limits of the Criminal Sanction 140 (1968).

180. OSHA, 29 U.S.C. $\$ 666$ (d) (1970).

181. See notes $69-73$ supra and accompanying text. The fact that the benefit of nonabatement does not accrue to any specific individual does not detract from the remedial nature of the civil fine for non-abatement nor from the similarity between those fines and sanctions for civil contempt. OSHA's civil penalty for non-abatement typifies the kind of administrative sanction envisioned by Professor Schwenk, see notes 102-04 supra and accompanying text. The purpose of the sanction is to coerce a violator into compliance, not to deter a potential violator as is characteristic of the criminal law. Enforcement by the government is appropriate where, as here, the purpose of a sanction is to remedy a hazard before an actual injury occurs. Clearly, few individuals could afford the expense of litigating an OSHA violation before the fact of injury. Mendoza-Martinez clearly contemplates government enforcement of such nonpenal regulatory schemes. See notes 97-111 supra and accompanying text.

182. The Third Circuit has explicitly recognized the validity of civil penalties like section $666(\mathrm{~d})$, which are designed to coerce compliance with regulations. In Irey $I$, the three-judge panel explained that "a deliberate and conscious refusal to abate a hazardous condition may bring about a situation where a heavy civil penalty might be needed to effect compliance with safety standards." Irey I 1204.

The problem with Irey $I$ is that the court appeared to apply this principle to the provision sanctioning willful violations, 29 U.S.C. $\$ 666$ (a) (1970), a provision conditioned on the willful violation of the Act, not on a refusal to abate a hazard. The large 


\section{Seventh Amendment Limitations}

Even when it is determined that imposition of a statutory sanction does not require the procedural protections associated with the criminal law, federal admimistrative adjudications may still be inappropriate unless accompanied by some provision for plenary judicial review. ${ }^{183}$ The seventh amendment requirement that "the right to trial by jury . . . be preserved" in significant "[s]uits at common law"184 places an important limit on the extent to which civil penalties can be administratively imposed $^{185}$ without provision for de novo review in district court. ${ }^{186}$ Even where Congress has the power to delegate adjudicative authority to an administrative agency, the seventh amendment may restrict the use of such a forum as a fimder of fact when the issue in controversy is in the nature of a suit at common law. ${ }^{187}$

The seventh amendment right to trial by jury represents a constitutional decision concerning "the preferable mode of disposing of issues of

penalty is designed to deter conduct by punishing its occurrence. The sanction for non-abatement is a method of coercing compliance.

183. It should be stressed from the outset that the seventh amendment right to trial by jury affects only federal administrative schemes since the Court has consistently refused to apply the seventh amendment to the States. Minneapolis \& St. L. R.R. v. Bombolis, 241 U.S. 211 (1916). It should be noted, however, that many state constitutions have similar provisions protecting the right to trial by jury in some or all civil cases, e.g., ILL. Const. art. I, \& 13; PA. Const. art. I, § 6; VA. ConsT. art. I, § 11, and that the resolution of the seventh amendment issue for the federal courts may take on added significance since the states frequently look to Supreme Court constructions of constitutional provisions in construing analogous provisions of their own constitutions. See, e.g., Serrano v. Priest, 5 Cal. 3d 584, 487 P.2d 1241, 96 Cal. Rptr. 601 (1971); Robinson v. Cahill, 303 A.2d 273 (N.J. 1973).

184. U.S. CoNST. amend. VII requires that:

In Suits at common law, where the value in controversy shall exceed twenty dollars, the right to trial by jury shall be preserved . . . .

185. L. JAFFE 90-91; see Irey II 1219; K. DAvIS $\$ 2.12$; J. MOORE $\mathbb{1}$ 38.11[7] at 128; Note, Application of Constitutional Guarantees of Jury Trial to the Administrative Process, 56 HARv. L. Rev. 282 (1942). See also J. MOORE at II 38.08[5] at 87; id. II 38.37[3] at 308.4. See authorities cited at note 203 infra.

186. If the seventh amendment does require that trial by jury be available, only a plenary trial in district court will satisfy that requirement. See L. JafFe 90. Contra, Irey 1I. This has been the thrust of the recent seventh amendment challenges to OSHA, which were directed not to the Occupational Health and Safety Review Commission's adjudicatory powers, but to the fact that the only judicial review which the Act permitted of the administrative agency's factual findings was limited by the substantial evidence test. Irey II 1215; Atlas Roofing 1011.

187. L. JAFFE 90-91. See James, Right to a Jury Trial in Civil Actions, 72 YALE L.J. 655,656 (1963). Throughout this analysis, a distinction is made between the power to delegate adjudicative authority and the restrictive effect which individual rights may have on that power. See generally L. JAFFE 90-92. There is little question, for example, that OSHA constitutes a legitimate exercise of the commerce power. See 29 U.S.C. $\$ 651$ (b) (1970); cf. Brennan v. OSHRC, 492 F.2d 1027, 1030 (2d Cir. 1974). Seventh amend- 
fact in civil cases at law."188 The absence of any provision protecting jury trials in civil cases was one of the most serious objections voiced by opponents of the original Constitution ${ }^{\mathbf{1 8 9}}$ who believed that the jury was an essential guardian of political and civil liberty. ${ }^{100}$ The seventh amendment was designed to act as a check against corruption, arbitrariness, and undue influence of wealth in the courtroom. ${ }^{191}$ Adherence to the federal policy favoring jury trials ${ }^{192}$ is nowhere more important than where the government is authorized to use the civil law to enforce its own regulations. ${ }^{193}$ In such cases, the amendment's function parallels that of the constitutional provisions for trial by jury in criminal casesprevention of oppressive government regulation. ${ }^{194}$

The concept of a "suit at common law" is central to any analysis of the applicabihty of the seventh amendment. While early cases appeared to limit the requirement of a civil jury to actions triable under common law rules as they existed when the seventh amendment was adopted in $1791,{ }^{195}$ later decisions have made it clear that a statutory right of action which involves legal rights carries the same seventh amendment guaran-

ment challenges to OSHA have been limited to the ground that the narrow scope of review allowed under the Act abrogates the iudividual's right to trial by jury, Irey II 1215; see Atlas Roofing 1011-12, and it should be emphasized that since it is the right to a jury, not the exercise of power, that is at issue, the mere presence of the judicial power in the enforcement scheme will not satisfy the amendinent. But see Irey II 1214.

188. Beacon Theatres, Inc. v. Westover, 359 U.S. 500, 501 (1959); Dimick v. Scheidt, 293 U.S. 474, 485-86 (1935).

189. Colegrove v. Battin, 413 U.S. 149, 152-55 (1973); Galloway v. United States, 319 U.S. 372, 398-99 (1943) (Black, J., dissenting); Parsons v. Bedford, 28 U.S. (3 Pet.) 432, 446 (1830); see LIBRARY OF CoNGRESs, supra note 116, at 1231-32.

190. See Galloway v. United States, 319 U.S. 372, 397 (1943) (Black, J., dissenting); Parsons v. Bedford, 28 U.S. (3 Pet.) 432, 445-46 (1830); J. STORY, COMMENTARIES ON the Constitution of the United States $\$ 1757$ (1833). See also 3 W. Blackstone, COMMENTARIES $* 379$.

191. Cf. Dimick v. Schiedt, 293 U.S. 474, 485-86 (1935), citing 3 W. BlackSTONE, Commentaries *348, *379-80; J. MOORE TI 38.02[1] at 17-18.

192. Sce Simler v. Conner, 372 U.S. 221, 222 (1963); Beacon Theatres, Inc. v. Westover, 359 U.S. 500, 501 (1959); C. WRIGHT, HANDBOOK OF tHE LAW OF FedERAL CourTs \$ 92, at 402-03 (2d cd. 1970).

193. Dean McKay has commented on the enhanced dangers of biased adjudications by administrative officers who are highly committed to the goals of the administrative scheme in which they are involved. McKay, Sanctions in Motion: The Administrative Process, 49 Iowa L. Rev. 441, 442, 473 (1964).

194. See notes 40-44 supra and accompanying text. As a result, the fundamental issue in applying the seventh amendment to statutory schemes for administrative imposition of money penalties is analogous to that of the sixth amendment analysis presented earlier: To what degree may the need for constitutionally required procedures be undercut by legislative act? See notes 45-51 supra and accompanying text. See also United States v. Jepson, 90 F. Supp. 983, 986 (D.N.J. 1950), discussed in note 198 infra.

195. See Galloway v. United States, 319 U.S. 372, 388 (1943); Dimick v. Scheidt, 293 U.S. 474, 487 (1935); Note, supra note 185, at 283. 
tee as its common law counterpart. ${ }^{196}$ Where legislation provides for the enforcement of statutory rights and remedies analogous to those recognized at common law in "an ordinary civil action in district court," the seventh amendment requires that a jury trial be made available. ${ }^{107}$ Thus, there is little question that any original judicial imposition of a statutory money penalty will entitle the defendant to trial by jury, regardless of whether the particular sanction existed at common law in $1791 . .^{198}$

196. Curtis v. Loether, 415 U.S. 189, 193-94 (1974) ("The Seventh Amendment does apply to actions enforcing statutory rights . . ."); United States v. J.B. Williams, Inc., 498 F.2d 414, 422-23 (2d Cir. 1974); see Pernell v. Southall Realty, 416 U.S. 363, 37476 (1974); Ross v. Bernhard, 396 U.S. 531, 533 (1970), citing Parsons v. Bedford, 28 U.S. (3 Pet.) 433, 447 (1830).

197. Pernell v. Southall Realty, 416 U.S. 363 (1974); Curtis v. Loether, 415 U.S. 189, 193-97 (1974); United States v. J.B. Williams, Inc., 498 F.2d 414 (2d Cir. 1974).

Several situations should be distinguished. First, if a statute makes specific provision for trial by jury, the courts must respect that mandate regardless of whether a jury would have been constitutionally required. Michaelson v. United States, 266 U.S. 42, 64-67 (1924); J. MOORE TI 38.12[1] at 128.24. Second, if a statute is silent on the issue of trial by jury, the rights of action and proceeding must be analogized to their historical counterparts to determine whether the Constitution requires that trial by jury be available. Luria v. United States, 231 U.S. 9, 27-28 (1913); see, e.g., Pernell v. Southall Realty, 416 U.S. 363 (1974). See generally J. MOORE II 38.11[7] at 128.4; id. II 38.37[3]; 9 Wright \& Miller, Federal Practice aNd Procedure \$ 2302 (1971). According to the recent cases, this determination of whether an issue is of such a legal nature as to require a right to trial by jury depends on a consideration of the pre-merger custom with reference to such questions, the remedy sought, and the practical abilities and limitations of juries. Ross v. Bernhard, 396 U.S. 531, 538 n.10 (1970); Rogers v. Loether, 467 F.2d 1110, 1116-17 (7th Cir. 1972), aff'd sub nom. Curtis v. Loether, 415 U.S. 189 (1974). If any legal claim is presented, the opportunity for trial by jury must be afforded regardless of its combination with issues formerly adjudicated by a court of equity unless grave and unusual circumstances are presented. Dairy Queen, Inc. v. Wood, 369 U.S. 469, $472-73$ (1962); Beacon Theatres, Inc. v. Westover, 359 U.S. 500, 510-11 (1959). See note 230 infra.

A third situation arises where Congress enacts a statutory scheme which provides a new cause of aetion and a mode of enforcement that seems to preclude trial by jury. In this case, the legislation must be examined to determine whether it is violative of the seventh amendment. J. MOORE II 38.37[3] at 308.4; see, e.g., Pernell v. Southall Realty, 416 U.S. 363 (1974); Curtis v. Loether, 415 U.S. 189 (1974); Katchen v. Landy, 382 U.S. 323 (1966). Recent cases have clarified the mode of analysis for making this determination when the litigation is committed to a district court, Pernell v. Southall Realty, 416 U.S. 363, 383 (1974); Curtis v. Loether, 415 U.S. 189, 195 (1974); see United States v. J.B. Williams Co., 498 F.2d 414 (2d Cir. 1974); Note, supra note 45, at 522. However, the approach for cases in which nonjudicial forums are prescribed remains unclear. The balance of this Comment will present one possible approach.

198. United States v. Regan, 232 U.S. 37, 47 (1914); Hepner v. United States, 213 U.S. 103, 115 (1909); United States v. J.B. Williams, Inc., 498 F.2d 414, 422-23 (2d Cir. 1974); J. MOORE If 38.31[1] at 232-33; see Irey I 1207, 1215 (Gibbons, J., dissenting); Note, supra note 29 , at 547.

An action for a statutory penalty is an action for debt, and as the district court explained in United States v. Jepson, 90 F. Supp. 983 (D.N.J. 1950):

... [an] action does not lose its identity merely because it finds itself en- 


\section{De Novo Review and the Seventh Amendment}

The more difficult seventh amendment issue concerns the constitutionality of legislative schemes which preclude jury resolution of factual disputes by delegating adjudicative responsibility to administrative officials. ${ }^{100}$ Some authorities seem to have relied on the notion that trial by jury is incompatible with the concept of administrative adjudication to argue that all proceedings before an administrative agency are exempted from the seventh amendment. ${ }^{200}$ While this "administrative proceeding exception" may be defensible when the question is whether an administrative forum nust employ a jury as a finder of fact, ${ }^{201}$ it cannot justify the complete derogation of the constitutional right to a civil jury in common law cases. $^{202}$ The seventh aniendinent is an inportant constraint on the kinds of civil actions that can be resolved conclusively by administrative officers. ${ }^{203}$ When an administrative sanction is in the

meshed in a statute. The right to trial by jury in an action for debt still prevails whatever modern name may be applied to the action. To hold otherwise would open the way for Congress to nullify the constitutional right of trial by jury by mere statutory enactments. $1 d$. at 986 .

199. See, e.g., OSHA, 29 U.S.C. $\$ \S 660$ et seq. (1970). See note 11 supra. Largely because of the lack of such schemes, see note 5 supra, this issue has rarely been analyzed by the courts and does not appear to have been authoritatively resolved except in a few narrow situations. For example, it seems clear that the Government and another party can agree in contract to give an administrative agency final authority to impose penalties that are in the nature of liquidated damages. See note 89 supra; see Irey I 1214 n.10 (Gibbons, J., dissenting). Similarly, the liquidated damages theory may give an administrative agency authority to impose penalties on its licensee as a condition of the license. See note 90 supra. It should be emphasized, however, that such powers are unrelated to the kinds of money penalties present in OSHA where the Government has no specific prior relationship with a particular business. The power of some agencies to deny or revoke a license-a privilege which is regulated on behalf of Congress-is quite distinct from the power to impose a penalty on any member of the public. See L. JAFFE 111. But see Atlas Roofing 1012.

Finally, it should be noted that the "exclusive power" doctrine established in Oceanic Steam Navigation Co. v. Stranahan, 214 U.S. 320 (1909), see notes 117-33 supra and accompanying text, may also serve to exempt some administrative sanctions from the seventh amendment. See lrey $I$ 1209-12 (Gibbons, J., dissenting); Note, supra note 30, at 548-49 nn.47-49. Stranahan, however, would appear to be distinguishable since it was decided under admiralty jurisdiction, see Irey I 1208-11 (Gibbons, J., dissenting).

200. See generally Atlas Roofing 1011; Irey II 1216-17; Note, supra note 185, at 282. Professor Jaffe's comment that "the concept of expertise on which the administrative agency rests is not consistent with the use by it of a jury as fact finder," L. JAFFE 90 , has been frequently cited by the courts and commentators. See, e.g., Curtis v. Loether, 415 U.S. 189, 194 n.8 (1974); Developments in the Law-Employment Discrimination and Title VII of the Civil Rights Act of 1964, 84 HARv. L. REv. 1109, 1267 n.390 (1971).

201. See Beall Const. Co. v. OSHRC, 507 F.2d 1041, 1044 (8th Cir. 1974); Note, supra note 30 , at 544 . See also L. J JFFE 90.

202. See Irey I 1213 (Gibbons, J., dissenting); Irey II 1225 (Gibbons, J., dissenting); L. JAFFE 90; Note, supra note 185, at 282.

203. Most commentators and judges would agree, for example, that the seventh 
nature of a suit at common law, the seventh amendment mandates jury determination of the fact of wrongdoing before a penalty can be imposed. ${ }^{204}$ In inost cases, the amendment can be satisfied by provision for de novo review in district court, with only negligible effects on the efficacy of the particular regulatory scheme. ${ }^{205}$ Unfortunately the courts have not been attentive to developing a sound test for determining when the seventh amendment must be applied. ${ }^{200}$

\section{Equitable Remedies}

Many of the cases which have been cited in support of an admimistrative proceeding exception to the seventh amendinent provide hittle guidance, since they present situations which are so clearly outside the

amendment would prohibit Congress from establishing a National Torts Claim Board to adjudicate all tort actions under federal jurisdiction, subject to only limited judicial review. See Irey II 1219, 1220-22 (Gibbons, J., dissenting); K. Davis \$ 2.13; L. JAFFE 90; J. MOORE If 38.11[7] at 128-128.1; Hart, The Power of Congress to Limit the Jurisdiction of the Federal Courts: An Exercise in Dialectic, 66 HARv. L. REv. 1362, 1375 (1953); James, supra note 187, at 655-56; Developments in the Law, supra note 200 , at 1267 n.391.

204. A suit for a statutory penalty, for example, has historically been covered by the common law action for debt. See United States v. Regan, 232 U.S. 37, 47 (1914); Hepner v. United States, 213 U.S. 103, 115 (1909); United States v. J.B. Williams, Inc., 498 F.2d 414, 422-23 (2d Cir. 1974); J. MOORE If 38.11[7] at 128.2; Note, supra note 30 , at 547. The common law analogy and the seventh amendment's protections may not be diminished simply because Congress chooses to so legislate. See United States v. Jepson, 90 F. Supp. 983, 986 (D.N.J. 1950), discussed at note 198 supra. See also Irey I 1213; Irey II 1222 (Gibbons, J., dissenting).

In Irey I, Judge Gibbons focused on the summary district court action to collect a civil money penalty under OSHA, 29 U.S.C. $\$ 666(l)$ (1970). See note 30 supra. As another commentator has recently noted, this focus is misguided since a suit to execute a penalty may normally be disposed of summarily without a jury. Note, supra note 30 , at 547 . It is the original OSHA penalty proceeding that is analogous to the common law action for debt, and for that action to be conclusive, there must be an opportunity for trial by jury.

205. Even where provided, trials de novo are rarely sought, Irey $I 1205 \mathrm{n.11} ; \mathrm{H}$. GoLDSCHMD 899; L. JAFFE 99, 113. Yet the mere fact of their availability would appear to satisfy any seventh amendment objection. Irey II 1215; L. JAFFE 99; see Irey I 1205 n.11.

206. See, e.g., Irey II, where the Third Circuit held en banc:

There is a line beyond which Congress may not transfer traditional remedies from the courts to administrative agencies so as to evade the protection of the Seventh Amendment. As so often with constitutional adjudications, such a point need not be defined with precision to cover all cases for all time. We only decide the case before us, and, as the panel previously held, that line has not been crossed in this case. Irey II 1219 (footnote omitted).

See also Atlas Roofing 1011-12. The dissent in Irey II exposed the problems inherent in such a position:

[H] ow do we know the line has not been crossed if we are not told where it is? What neutral principle was brought to bear im deciding that this case fell on the permissible side of the invisible line? Irey II 1221 (Gibbons, J., dissenting). 
common law that trial by jury would not have been required even if the statute had prescribed adjudication in a district court. ${ }^{207}$ In Guthrie National Bank v. Guthrie, ${ }^{208}$ for example, the claims which the Oklahoma territorial legislature had established its special commission to adjudicate were purely equitable and therefore clearly outside the trial by jury guarantee of the seventh amendment. ${ }^{209}$ The case merely stands for the proposition that the seventh amendment will not bar administrative adjudication when the issue to be decided is equitable in nature. ${ }^{210}$

A sinilar rationale underlies the decisions which reject seventh amendment challenges to administrative and judicial awards of backpay. ${ }^{211}$ The Supreme Court and many of the appellate courts have refused to apply the seventh amendment to a variety of statutory schemes which permit administrative and judicial officers to render money judgments at their discretion as part of an equitable remedy designed to restore the parties to the positions they would have held had the statute not been violated. ${ }^{212}$ The money award is considered to be in the nature of restitution, an equitable remedy which does not entitle the parties to trial by jury. ${ }^{213}$ Most money penalties, however, are a necessary consequence of a finding that a violation has occurred and have no relationship to the wrongful gains or losses of any party. ${ }^{214}$ For this reason, it is difficult to reject a seventh amendment challenge to an

207. See cases cited in notes 208-19 infra.

208. 173 U.S. 528 (1899).

209. Id. at 537. The commission had been established to determine the validity of claims against certain municipalities; the claims had no basis in law because the debts were incurred before the cities had statutory authority to incur debts. Id. at 534 .

210. See id. at 536-37; cf. Rogers v. Loether, 467 F.2d 1110, 1121 n.37 (7th Cir. 1972), aff'd sub nom. Curtis v. Loether, 415 U.S. 189 (1974).

211. See, e.g., NLRB v. Jones \& Laughlin Steel Corp., 301 U.S. 1, 48 (1937); Harkless v. Sweeny Indep. School Dist., 427 F.2d 319, 324 (5th Cir. 1970), cert. denied, 400 U.S. 991 (1971); see cases cited in note 212 infra.

212. E.g., Mitchell v. DeMario Jewelry, Inc., 361 U.S. 288 (1960) (redress for employment discrimination); Porter v. Warner Holding Co., 328 U.S. 395, 399 (1946) (reimbursement of rents that were excessive under Emergency Price Control Act); McFerren v. County Bd. of Educ., 455 F.2d 199, 202-04 (6th Cir.), cert. denied, 407 U.S. 934 (1972); Robinson v. Lorillard Corp., 444 F.2d 791, 802 (4th Cir.), cert. denied, 404 U.S. 1006 (1971); Harkless v. Sweeny Indep. School Dist., 417 F.2d 319, 324 (5th Cir. 1970), cert. dented, 400 U.S. 991 (1971); see Albemarle Paper Co. v. Moody, 422 U.S. 405, $442-44$ (1975) (Rehnquist, J., concurring). The equitable remedy of restitution has traditionally been used to restore parties to the status quo. J. Moore II 38.24[2] at 190.5. See generally D. DoBBs, supra note 83, \& 4.1 (1973).

213. See generally J. MOORE \ 38.24[2].

214. See Albemarle Paper Co. v. Moody, 422 U.S. 405, $442-44$ (1975) (Rehnquist, J., concurring). 
adininistrative penalty proceeding on the theory that it is an equitable measure in the nature of restitution.

Another theory that has been offered in support of administrative imposition of civil money penalties relies on a distinction between purely private actions and actions infused with a public interest. According to this argument, an action initiated by a public official may result in a money judgment without an opportunity for trial by jury when the action is aimed at the vindication of a "public right."215 Besides the obvious problein of distinguishing between public and private rights, ${ }^{216}$ the difficulty with this argument is that the "public interest" put forward to overcome a seventh amendment challenge has uniformly been that of affording coinplete relief to the parties by restoring each to the status it would have held but for the statutory violation. ${ }^{217}$ Thus, the inoney awards in this line of cases are essentially equitable reniedies in the nature of restitution. ${ }^{218}$ While it is true that assertion of a public right inay enable Congress to delegate adjudicatory power to administrative agencies, that jurisdictional argument does not permit Congress to undercut the seventh amendment right to trial by jury in significant cases at common law. ${ }^{219}$ Thus, the public right argument may only be used

215. See H. Goldschmid 943; Brief for Respondent at 10, Irey $I 1$.

216. At least one court and several commentators have noticed the analytical difficulties in any such distinction. Rogers v. Loether, 467 F.2d 1110, 1121 n.37 (7th Cir. 1972) (opinion of Stevens, J.), aff'd sub nom. Curtis v. Loether, 415 U.S. 189 (1974); Comment, The Seventh Amendment and Civil Rights Statutes: History Adrift in a Maelstrom, 68 Nw. U.L. REV. 503, 517-19 (1973) (also notes the lack of historical precedent for such a distinction); Note, The Right to Jury Trial Under Title VII of the Civil Rights Act of 1964, 37 U. CHr. L. Rev. 167, 175-76 (1969); see L. JAFFE 90; Jaffe, The Public Right Dogma in Labor Board Cases, 59 Harv. L. Rev. 720 (1946).

217. See, e.g., Mitchell v. DeMario Jewelry, Inc., 361 U.S. 288, 291 (1960), quoting Porter v. Warner Holding Co., 328 U.S. 395, $397-98$ (1946); McFerren v. County Bd. of Educ., 455 F.2d 199, 202 (6th Cir.), cert. denied, 407 U.S. 934 (1972); Harkless v. Sweeny Indep. School Dist., 427 F.2d 319 (5th Cir. 1970), cert. denied, 400 U.S. 991 (1971) (redress of employment discrimination); Wirtz v. Jones, 340 F.2d 901, 904-05 (5th Cir. 1965) (order to pay withheld minimum or overtime wages under the Fair Labor Standards Act); Agwilines, Inc. v. NLRB, 87 F.2d 146 (5th Cir. 1936) (backpay order under National Labor Relations Act). See also Rogers v. Loether, 467 F.2d 1110, 1121 n.37 (7th Cir. 1972), aff'd sub nom. Curtis v. Loether, 415 U.S. 189, 196-97 (1974).

218. Compare Mitchell v. DeMario Jewelry, Inc., 361 U.S. 288, 293-96 (1960), and Porter v. Warner Holding Co., 328 U.S. 395, 399-400 (1946), with Curtis v. Loether, 415 U.S. 189, 196-97 (1974), aff'g Rogers v. Loether, 467 F.2d 1110 (7th Cir. 1972).

219. L. JAFFE 90. It is clear that a public right argument will not overcome a seventh amendment challenge unless the proceeding is outside the coinmon law. A public interest will not, in itself, be sufficient to remove an action from the common law. Id. at 90-91; see Rogers v. Loether, 467 F.2d 1110, 1121 n.37 (7th Cir. 1972), aff'd sub nom. Curtis v. Loether, 415 U.S. 189 (1974). Some advocates of a broad congressional power to delegate adjudicative authority to administrative agencies may have confused 
to support a broad use of equity powers in suits for restitution-suits which are quite distinct from actions for civil penalties.

\section{Administrative Proceedings and the Seventh Amendment}

Much of the dispute over the applicability of the seventh amendnent to legislation which provides for administrative imposition of unoney penalties centers around language in NLRB $v$. Jones \& Laughlin Steel $\mathrm{Co}^{220}$ In that case, the petitioning steel conpany challenged provisions of the National Labor Relations Act of $1935^{221}$ which authorized the NLRB to couple an award of backpay with a reinstatement order. ${ }^{222}$ While the thrust of the attack on the statute was directed at the Act's validity as an exercise of the commerce clause, ${ }^{223}$ the challenge did include a seventh amendment argunient that an award of backpay is equivalent to a money judgment and requires provision for trial by jury. ${ }^{224}$ The Court rejected the seventh amendment arguinent on two grounds: first, the award of backpay was nerely incidental to the equitable relief-reinstatement-that was the gravamen of the action;

this distinction between the jurisdictional and seventh amendment consequences of a "public right." See, e.g., H. GoLDsCHMD 943.

It should be noted that the case which first suggested the public right doctrine, Murray's Lessee v. Hoboken Land \& Improvement Co., 59 U.S. (18 How.) 272, 284 (1855), did so in the context of a discussion of equitable rights and remedies. Murray's Lessee involved Congress' power to authorize executive officers to put a lien on the properties of a tax collector who, after an accounting, was found unable to transmit the sum he had collected to the U.S. Treasury. See Irey $I 1211$ (Gibbons, J., dissenting); L. JAFFE 88-90. While a seventh amendment argument had been asserted, 59 U.S. at 273 , it was not discussed by the Court. See Irey I 1212 (Gibbons, J., dissenting). This may have been because of a standing problem stemming from the fact that the suit was brought not by the tax collector, but by remote successors to his title in certain lands, or because the seventh amendment challenge was not taken seriously since the case dealt in essence with "[t]he enforcement of the duty of a fiduciary to account," an equitable right historically outside the scope of the seventh amendment. Id. Judge Gibbons also distinguished Murray's Lessee from cases treating in personam judgments as civil money penalties because the case dealt with what was essentially an in rem proceeding-execution of a tax warrant on the tax collector's property. Id.

220. 301 U.S. 1 (1937). The dispute over the rule of Jones \& Laughlin, see notes 225-27 infra and accompanying text, is epitomized in the conflict between the majority and dissenting judges in Irey II. Compare Irey II 1216-17 with Irey II 1221-24 (Gibbons, J., dissenting) and id. at 1226 (Gurth, J., dissenting). Also compare Irey $I$ at $1205 \mathrm{n} .11$ with id. at 1209-15 (Gibbons, J., dissenting).

221. Act of July 5,1935, c. 372 , $\S \S 1-16,49$ Stat. 449 (codified as amended at 29 U.S.C. $\$ \S 151$ et seq. (Supp. III, 1973)).

222. Id. $\$ 10(\mathrm{c}), 49$ Stat. at 454 .

223. See NLRB v. Jones \& Laughlin Steel Co., 301 U.S. 1, 13-19, 29-41 (1937). It is difficult to believe that the Supreme Court intended Jones \& Laughlin to create an important exception to the seventh amendment, since it saw fit to dispose of the issue in only one page of a 49-page opmion. See Irey II 1224 (Gibbons, J., dissenting).

224. NLRB v. Jones \& Laughlin Steel Co., 301 U.S. 1, 48 (1937). 
and second, the proceeding was a "statutory proceeding" "unknown to the common law." 225

The difficulty with Jones \& Laughlin is that the scope of its holding is unclear. The opinion niay be read broadly as presenting the rule that the seventh amendment simply does not apply to any statutory scheme in which Congress has specifically provided for administrative adjudication. $^{226}$ On the other hand, the case may be read for the narrower principle that the amendnient does not apply to an adininistrative proceeding in which the award of backpay is part of a scheme of equitable relief contemplated by statute; in such a situation, the action is not in the nature of a suit at common law. ${ }^{227}$

225. Id.; JAFFE 91; Developments in the Law, supra note 200, at 1267 n.388.

226. E.g., Irey II 1216-17; see Atlas Roofing 1011-12; Irey I 1205 n.11. Such a reading has found wide acceptance, with its proponents stressing the fact that a "statutory proceeding" is alien to the common law. See Rogers v. Loether, 467 F.2d 1110, 1115-16 nn.15-18 (7th Cir. 1972), aff'd sub nom. Curtis v. Loether, 415 U.S. 189 (1974); J. MOORE TI 38.08[5]; Walker, Title VII: Complaint \& Enforcement Procedures and Relief and Remedies, 7 B.C. Indus. \& Comm. L. Rev. 495, 507-08 (1966); Developments in the Law, supra note 200, at 1267-68 n.388; Comment, supra note 47, at 350. This interpretation is particularly plausible given the decision in Dimick v. Schiedt, 293 U.S. 474 (1935) (5-4 decision holding the seventh amendment to be a bar to the use of additur in the federal courts), decided less than two years before hearing of Jones \& Laughlin. In that case, the majority advanced the rigid theory that the common law as it stood in 1791 was incorporated in the seventh amendment. Id. at 487. According to that view, any statutory proceeding would be unknown to the common law and beyond the strictures of the seventh amendment. See Note, supra note 185, at 283.

227. Irey I 1214 (Gibbons, J., dissenting); Irey II 1221-23 (Gibbons, J., dissenting); id. at 1226 (Garth, J., dissenting) (follows legal reasoning of Gibbons' dissents); Note, supra note 30 , at 548 . This interpretation flows from the more flexible position asserted by the dissenting justices in Dimick v. Schiedt, 293 U.S. 474, 490-91 (1935) (Stone, J., dissenting) (5-4). The Dimick dissent suggested that the common law was not frozen as of 1791 but had continued to develop and that the seventh amendment would apply to a new procedure if the matter at issue was analogous to a common law issue. See Note, supra note 185 , at 283 . The Dimick minority interpretation is clearly the view of the seventh amendment which has since been adopted by the Court. See, e.g., Dairy Queen, Inc. v. Wood, 369 U.S. 469 (1962); Beacon Theatres, Inc. v. Westover, 359 U.S. 500 (1959). Under this view, the NLRB proceeding would have been examined, the money damages held incidental to the equitable relief of reinstatement provided by statute, and the seventh amendment thus held inapplicable. While the recent cases reject this equitable clean-up doctrine, Dairy Queen, Inc. v. Wood, 369 U.S. 469, $470-73$ (1962) (see note 230 infra), it was clearly viable during the period in which Jones \& Laugllin was decided. See generally J. MOORE II 38.16[1].

The citation of Guthrie National Bank v. Guthrie, 173 U.S. 528,537 (1899) in support of the proposition that "[the seventh amendment] does not apply where the proceeding is not in the nature of a suit at common law," NLRB v. Jones \& Laughlin Steel Co., 301 U.S. 1, 48 (1937), supports this narrow interpretation. Guthrie involved a special commission set up by the Oklahoina territorial legislature to hear clains against the town of Guthrie. These clamis had no legal force, but the legislature deemed it equitable to determine their moral worth and honor them where appropriate. 173 U.S. 


\section{The Modern Test: Substantial Necessity}

The modern cases suggest an intermediate position. As the Supreme Court recently announced in Curtis v. Loether: ${ }^{228}$

Jones \& Laughlin merely stands for the proposition that the Seventh Amendment is generally inapplicable in administrative proceedings, where jury trial would be incompatible with the whole concept of administrative adjudication and would substantially interfere with [the agency's] role in the statutory scheme. 228

It is unreasonable to believe that this gloss on the holding of Jones \& Laughlin does no more than restate the truism that trial by jury is incompatible with administrative adjudication. Rather, the interpretation should be read as a particularization of the modern rule of equity that characterization of legal claims as incidental or prior to equitable claims can result in the loss of a right to trial by jury "only in the most imperative circumstances." ${ }^{230}$ The administrative proceeding exception

at 534,537 . Thus the claim and the proceeding established to determine the claim were equitable in nature and the seventh amendment was held inapplicable. Id. at 537; see Rogers v. Loether, 467 F.2d 1110, 1115 n.16 (7th Cir. 1972), aff'd sub nom. Curtis v. Loether, 415 U.S. 189 (1974). The same rationale supports the holding in Jones \& Laughlin. In holding that the essence of the NLRB action was equitable and that the procedure for determining the claim and fashioning the remedy was equitable and outside the seventh amendment, the Court need not have held all statutory proceedings to be outside the purview of the seventh amendment. See J. MOORE II 38.37[3]; id. II $38.11[7]$ at 128.1 .

228. 415 U.S. 189 (1974).

229. Id. at 194 (emphasis added).

230. Dairy Queen, Inc. v. Wood, 369 U.S. 469, $472-73$ (1962); Beacon Theatres, Inc. v. Westover, 359 U.S. 500, 510-11 (1959); see Ross v. Bernhard, 396 U.S. 531, 538-40 (1970).

Beacon Theatres and Dairy Queen dramatically expanded the jury trial guarantee of the seventh amendment. J. MOORE II 38.12[1]; 9 C. WRIGHT \& A. MILLER, supra note $197 \S 2302$, at 21; see Ross v. Bernhard, 396 U.S. 531,537 (1970). Those cases made it clear that the scope of equity had been diminished by the increased flexibility of the legal remedies provided by the Federal Rules of Civil Procedure and the Declaratory Judgment Act. Dairy Queen, Inc. v. Wood, 369 U.S. 469, 478 n.19 (1962); Beacon Theatres, Inc. v. Westover, 359 U.S. 500, 508-09 (1959). Since the Federal Rules allow issues of law and equity to be decided together in one civil action, with the former decided by a jury, requirements of judicial economy no longer justify equity's deciding legal issues when it obtains jurisdiction. 359 U.S. at 508-09. Consequently, the cases required that vihere equitable and legal issues were joined in a single case, the right to trial by jury could be lost only in the "most imperative circumstances." Dairy Queen, Inc. v. Wood, 369 U.S. 469, at 472-73; Beacon Theatres, Inc. v. Westover, 359 U.S. 500, 510-11 (1959).

The Court has never specifically applied Beacon Theatres or its progeny to an administrative proceeding. Many commentators seem to have assumed that the line of cases would apply and that the narrow holding of Jones \& Laughlin, see note 227 supra and accompanying text, would simply lose its force. See, e.g., Rogers v. Loether, 467 F.2d 1110, 1118-20 (7th Cir. 1972) (opinion of Stevens, J.), affd sub nom. Curtis v. 
to the seventh amendment is limited to these situations where provision for trial by jury would "substantially interfere" with the administrative agency's role in a statutory scheme-where provision for trial by jury would be inconsistent with the whole concept of administrative adjudication as embodied in the legislative blueprint at hand. ${ }^{231}$ The test is necessarily a flexible one which nuust be applied on a case by case basis. Nonetheless, each administrative scheme which may infringe upon the seventh amendment must be carefully scrutinized. ${ }^{232}$ The issue is not one of legislative convemience but of substantial necessity to the efficacy of a statutory scheme. ${ }^{233}$ In essence, the question is not whether an administrative law judge must employ a jury as a fact finder, but whether some sort of review by a court einploying a jury would be destructive of an entire regulatory design.

This interpretation is supported by the few cases in which the Supreme Court has sustamed the power of Congress "to entrust enforcement of statutory rights to an administrative process or specialized court of equity free from the strictures of the Seventh Amendinent."234 In each of these cases, the holding has rested on a judicial determination that administrative adjudication was substantially necessary to the efficacy of the legislative scheine at issue. In Block v. Hirsh, ${ }^{235}$ for example, the Court upheld legislation which temporarily established a commission to regulate the duration and conditions of the possession of rented realty in the District of Columbia as a reasonable method of dealing with wartime overcrowding im Washington. ${ }^{236}$ A seventh amendment claim

Loether, 415 U.S. 189 (1974); Developments in the Law, supra note 200, at 1267 n.388. However, this is not necessarily true. There is no reason to suspect that Beacon Theatres does not apply to administrative proceedings. The test is whether the problems which require administrative adjudication constitute the imperative circumstances needed to satisfy the mandate of Beacon Theatres. See, e.g., Katchen v. Landy, 382 U.S. 323 (1966). See also Pernell v. Southall Realty, 416 U.S. 363, 383 (1974); Curtis v. Loether, 415 U.S. 189, 194-95 (1974).

231. See text accompanyiug note 229 supra.

232. As the Supreme Court explained in Beacon Theatres: "Maintenance of the jury as a fact-finding body is of such importance and occupies so firm a place in our history and jurisprudence that any seeming curtailment of the right to a jury trial should be scrutimized with the utmost care." " 359 U.S. at 501 (1959), quoting Dimick v. Schiedt, 293 U.S. 474, 486 (1935).

233. Note, supra note 185 , at 294 ; see Note, supra note 30 , at 550.

234. Curtis v. Loether, 415 U.S. 189, 195 (1974), citing Katchen v. Landy, 382 U.S. 323 (1966); NLRB v. Jones \& Laughlin Steel Co., 301 U.S. 1 (1937); Guthrie Nat'l Bank v. Guthrie, 173 U.S. 528 (1899); see Pernell v. Southall Realty, 416 U.S. 363, 382-83 (1974), citing Block v. Hirsh, 256 U.S. 135 (1921).

235. 256 U.S. 135 (1921), sustaining Act of October 22, 1919, ch. 80, tit. II, 41 Stat. 297 (1919).

236. 256 U.S, 135 (1921). 
to trial by jury was rejected, ${ }^{237}$ despite the fact that an action to recover possession was clearly recognized at common law. ${ }^{238}$ The Court reasoned that the power to decide the facts which affected the landlordtenant relationship was so inseparable from the authority to regulate that relation that the seventh anendment could not restrict the commission's adjudicative authority once its power to regulate the relation was established. ${ }^{230}$ The power to resolve issues of fact was deemed necessary to the efficacy of the legislative scheme.

More recently, a similar analysis was conducted in Katchen $v$. Landy ${ }^{240}$ in which the Supreme Court rejected a seventh amendment challenge to a bankruptcy court's summary jurisdiction to order the surrender of a voidable preference. ${ }^{241}$ Though it clearly recognized that the essentially legal issue of preference would normally entitle a party to trial by jury in a court of law, ${ }^{242}$ the Court refused to require the bankruptcy court to defer judgment until the creditor could coinplete a plenary proceeding in district court. ${ }^{243}$ Rather, the Court held, the situation disclosed the kind of imperative circumstances which permit a court of equity to resolve all issues before it even though the results might be dispositive of a legal claim which would otherwise entitle the

237. Id. at 157-58.

238. See Pernell v. Southall Realty, 416 U.S. 363, 371-74 (1974) (demonstrates the common law nature of suits for possession).

239. 256 U.S. at 158. Recently the Supreme Court has discussed the effect of Block in language almost ideutical to its statement of the rule of Jones \& Laughlin:

Block v. Hirsh merely stands for the principle that the Seventh Amendment

is generally inapplicable in administrative proceedings, where jury trials would be incompatible with the whole concept of administrative adjudication. Pernell v. Southall Realty, 416 U.S. 363, 383 (1974).

Compare id. with Curtis v. Loether, 415 U.S. 189, 194 (1974) (stating the rule of Jones \& Laughlin), set out in full in text accompanying note 229 supra.

This analysis of Block helps clarify the dictum from Pernell v. Southall Realty, 416 U.S. 363 (1974), where the Court suggests "that the Seventh Amendment would not be a bar to a congressional effort to entrust landlord-tenant disputes, including those over the right to possession, to an administrative agency." Id. at 383. The Court is simply reaffirming the principle that legislation can establish an administrative agency to examine and alter common law relationships. Where the ability to adjudicate and enforce such quasi-legislative determinations of the relationships between parties is necessary to the success of the legislative scheme, the seventh amendment may not impede that purpose.

240. 382 U.S. 323 (1966).

241. Id. at 325 .

242. Id. at 338-39.

243. Id. The petitioner argued that the bankruptcy court should be required to stay its proceedings and order the bankruptcy trustee to attempt to recover the preference by a plenary suit under 11 U.S.C. $\$ 96$ (1970); in such an action, a jury trial would have been available to the petitioner. See id. at 338 . 
parties to trial by jury. ${ }^{244}$ According to the Court, provision for jury trials would "dismember" the statutory scheme which Congress had designed "to secure prompt and effectual administration and settlement of the estate of all bankrupts in a limited period."245 The necessity for a speedy and complete estate settlement provided the "imperative circumstances" necessary to extricate the proceeding from the requirements of the seventh amendment. ${ }^{246}$

Block and Katchen each suggest the kinds of needs which may help to justify a scheme for administrative penalty imposition that precludes an opportunity for trial by jury. The needs of technical expertise, rapid adjudication, and uniform results based on fluctuating public demands may all be considered in determining whether to remove an administrative program from the scope of the seventh amendment. ${ }^{247}$

Application of these considerations to administrative imposition of money penalties is necessarily difficult in the absence of a specific legislative scheme, but certain general principles can be suggested. First, civil money penalties must be considered prima facie within the seventh amendment. ${ }^{248}$ In personam judgments for civil fimes have long been

244. Compare id. at 329 with id. at 338, citing Dairy Queen, Inc. v. Wood, 369 U.S. $469,472-73$ (1962).

245. 382 U.S. at 328-29; see D. DoBBS, supra note 83, $\$ 2.6$, at 77 n.44 (1973).

246. 382 U.S. at $338-40$. See note 230 supra and accompanying text.

247. See note 252 infra. It should be emphasized that no one of these factors will necessarily be sufficient to move the proceeding into the domain of equity. The Supreme Court, for example, has made it quite clear that a desire for speed-a factor frequently cited in support of conclusive administrative adjudication-will only rarely be sufficient to obviate the need for trial by jury. See Pernell v. Southall Realty, 416 U.S. 363,384 (1974) ("[W]e reject the notion that there is some necessary inconsistency between the desire for speedy justice and the right to a jury trial.").

248. But see Irey II 1218. Unwilling to accept that the difference between a civil penalty payable to the United States and an award of backpay might have constitutional implications, the Third Circuit refused to accord any significance to the dissenter's analogy between civil fines and the common law action for debt. Compare id. with id. at 1222-24 (Gibbons, J., dissenting); Irey I 1208, 1213 (Gibbons, J., dissenting). In part, the Third Circuit's position was the result of a misreading of Curtis v. Loether, 415 U.S. 189 (1974), which the Irey majority cited in support of the proposition that the similarity between OSHA's civil penalties and an in personam money judgment obtainable only at law was not decisive of the seventh amendment issue. Irey II 1218. While Curtis did indicate that not all monetary relief would necessarily be characterized as legal, 415 U.S. at 196, that case strongly suggested that the difference between an award of backpay as part of an equitable remedy, see notes 211-14 supra and accompanying text, and other monetary awards that were traditionally offered by courts of law would be determinative in applying the seventh amendment, 415 U.S. at 195-97; see Pernell v. Southall Realty, 416 U.S. 363, 370, 375 (1974) (" . . . where an action is simply for the recovery ... of a money judgment, the action is one at law." Id. at 370, quoting Whitehead v. Shattuck, 138 U.S. 146, 151 (1891)). While it is true that a money judgment has the same impact on an individual whether it is the result of an equitable 
considered part of the common law notwithstanding their statutory origins. ${ }^{249}$ Since they are legal in nature, they may not be upheld under the rule of Guthrie, which applies only to purely equitable claims. ${ }^{250}$ Similarly, money fines may not be protected under the restitution rationale since they have no relationship to any wrongful gain or loss by any party and are a natural consequence of a wrongful act rather than a discretionary reinedy designed to secure total justice. ${ }^{251}$ Second, in any given case, the test must focus on the incompatibility of jury determination of facts with the statutory scheme at issue. Mere convenience is not a sufficient standard. To overcome a seventh amendment challenge, preclusion of all opportunity for trial by jury must be necessary to the success of the statutory schenie. Some evidence beyond the congressional authorization of the challenged procedure inust therefore be presented if the administrative scheme is to be upheld. ${ }^{252}$

award of backpay or an award of a statutory penalty at law, Irey II 1218, that similarity has no meaning in the seventh amendment context. The issue is whether "the action involves rights and remedies of the sort traditionally enforced in an action at law, rather than in an action in equity or admiralty." Pernell v. Southall Realty, 416 U.S. 363, 375 (1974).

249. United States v. Regan, 232 U.S. 37 (1914); Hepner v. United States, 213 U.S. 103, 115 (1909); United States v. J.B. Williams Co., 498 F.2d 414, $422-23$ (2d Cir. 1974); J. MOORE II 38.31[1] at 232-33; see Irey I (Gibbons, J., dissenting); Irey II (Gibbons, J., dissenting). See also Pernell v. Southall Realty, 416 U.S. 363, 370, 375 (1974).

250. See notes 208-10 supra and accompanying text.

251. See notes 213-14 supra and accompanying text.

252. There are some criteria of general applicability which should be considered in evaluating any seventh amendment challenge to a scheine for administrative imposition of money penalties which makes no provision for trial by jury. First, "the use of administrative sanctions is justifiable mainly in respect of inatters already or typically committed to administrative supervision and control .... The admistrative power to penalize should be an incident of other functions, rather than an activity standing alone." Gellhorn, supra note 92, at 285.

More specifically, the Administrative Conference of the United States has proposed a set of guidelines for assessing the desirability of allowing administrative agencies to impose penalties subject to only limited judicial review:

(a) a large volume of cases likely to be processed annually;

(b) the availability to the agency of more potent sanctions with the resulting likelihood that civil money penalties will be used to moderate an otherwise too harsh response;

(c) the importance to the enforcement scheme of speedy adjudications;

(d) the need for specialized knowledge and agency expertise in the resolution of disputed issues;

(e) the relative rarity of issues of law (e.g., statutory interpretation) which require judicial resolution;

(f) the importance of greater consistency of outcome (particularly as to penalties imposed) which could result from agency, as opposed to district court, adjudications; and

(g) the likelihood that an agency (or a group of agencies in combination) will establish an impartial forum in which cases can be efficiently and fairly decided.

Recommendation 72-6: Civil Money Penalties as a Sanction, 2 ReCOMMEN- 


\section{Application of the Seventh Amendment to OSHA}

This analysis suggests that OSHA's civil penalties for willful ${ }^{253}$ and non-willful violations ${ }^{254}$ may not be imposed unless the alleged violator is given an opportunity for trial by jury. ${ }^{255}$ While it may be argued that these money penalties are merely incidental to the OSHA proceeding's essentially equitable purpose of ordering abatement, ${ }^{258}$ the modern cases make it clear that the right to a jury trial of legal issues cannot be swallowed up in an equitable proceeding absent some extraordinary policy needs. ${ }^{257}$ OSHA was designed to cope with a difficult problem on a national scale; ${ }^{258}$ however, neither its legislative history nor independent analysis discloses any reason why an opportunity for trial by jury would be incompatible with the purpose or efficacy of the Act. ${ }^{259}$

An opportumity for de novo review in district court is unlikely to impede the speedy resolution of issues contemplated by the Act. A wide variety of regulatory schemes presently depends on a de novo trial for the recovery of civil penalties. ${ }^{260}$ OSHA's procedure of finalizing

Dations AND Reports OF THE ADMINISTRATtVe CONFERENCE OF THE UNITED STATES 69 (1972).

These factors are consistent with many of the special needs contemplated by the case law. See notes 234-47 supra and accompanying text. They are also important in efforts to reduce the inequitable system of penalty settlements which presently results from the inability of the Department of Justice to act in concert with various administrative agencies in successfully completing the process of imposing fines on violators through the courts. See generally H. GoLDSCHMID. It is possible that this problem itself may constitute a danger to some regulatory schemes which is so severe that conclusive administrative adjudication of penalties, as in OSHA, is justified.

In general, it will take more than one of the above factors to justify removing a particular legislative scheme from the scope of the seventh amendinent. See note 247 supra.

253. OSHA, 29 U.S.C. $\S 666$ (a) (1970).

254. Id. $\$ \S 666(\mathrm{~b}),(\mathrm{c})$.

255. Irey I (Gibbons, J, dissenting); Irey II (Gibbons, J., dissenting); Note, supra note 30, at 550-51. Contra, Irey 1 ; Irey II; Atlas Roofing.

256. Brief for Respondent Secretary of Labor on rehearing of Frank Irey, Ir., Inc. v. OSHRC at 12; see Irey II 1219.

Some members of the Third Circuit refused to accept the "incidental" argument on its face, finding that recovery of a money judgment was the sole purpose of an OSHA penalty proceeding. Irey I 1213 (Gibbons, J., dissenting); Irey II 1222 (Gibbons, J., dissenting).

257. Dairy Queen, Inc. v. Wood, 369 U.S. 469, $472-73$ (1962); Beacon Theatres, Inc. v. Westover, 359 U.S. 500 (1959). See note 230 supra.

258. See OSHA, 29 U.S.C. § 651 (1970); Atlas Roofing 1493-94.

259. Irey I 1205 n.11, 1213-14 (Gibbons, J., dissenting).

260. E.g., 47 U.S.C. $\$ \S 503,504$ (1970) (FCC); United States v. J.B. Williams Co., 498 F.2d 414 (2d Cir. 1974) (requiring plenary proceedings to enforce penalties under the Federal Trade Commission Act, 15 U.S.C. $\$ 45(l)$ (Supp. III, 1973)).

In fact, very few federal agencies now have authority to impose money penalties 
Commission orders whenever a particular step in the review process is not taken within a specified period ${ }^{281}$ could continue to function to assure speedy disposition of contested citations without impinging on the seventh amendment. ${ }^{262}$

More importantly, application of the seventh amendment to these civil penalty provisions would not interfere with OSHA's primary purpose-the rapid abatement of hazardous working conditions. Under the Act's present provisions for judicial review, an appeal of a penalty citation does not stay the OSHRC's abatement order unless such a stay of execution is specifically ordered by the court. ${ }^{203}$ This procedure maintains the OSHRC's role as an expert body that is best equipped to determine when a hazard exists and to invest the time and effort which will be necessary for abatement. On the other hand, the Commission has no particular expertise in deciding factual issues such as intent and reasonable care. These issues, which are fundamental to the imposition of OSHA's civil penalties, are frequently resolved by juries in other areas of the law. ${ }^{204}$

The OSHRC could, however, retain its authority to order abatement and penalties for non-abatement subject to only limited judicial review. While the non-abatement penalty does constitute an in personam money judgment, its mechanics make it more nearly analogous to a contempt proceeding ${ }^{205}$ than to the traditional suit for statutory penalties, which has historically been considered an action at common law. The purpose of the non-abatement penalty is central to the Act: it is designed to encourage remedial action by penalizing refusal to coinply with a binding order. Indeed, when an OSHRC abatement order is enforced by the courts, it is done through a contempt proceeding with the penalty for non-abatement being one of the sanctions available to the court. $^{200}$ Since rapid abatement is the purpose of OSHA, and since

without de novo review; most agencies are required to resort to the courts. See note 5 supra.

261. OSHA, 29 U.S.C. $\$ \S 659-60$ (1970). See notes 31-39 supra and accompanying text.

262. Such an arrangement would parallel many contemporary schemes of administrative regulation, see note 260 supra, while giving the OSHRC conclusive adjudicative authority in the vast majority of cases since few individuals ever take advantage of their opportunity for de novo review. H. GoLDSCHMD 899 (nearly $90 \%$ of all cases involving administrative penalties make no use of the opportunity for de novo review when it is available); see Irey I 1205 n.11; L. JAFFE 99, 113.

263. OSHA, 29 U.S.C. $\$ 660$ (a) (1970).

264. See W. Prosser, supra note 71, § 37; cf. United States v. J.B. Williams Co., 498 F.2d 414, 429 (2d Cir. 1974).

265. See notes 69-73 supra and accompanying text.

266. OSHA, 29 U.S.C. $\$ 660$ (b) (1970). 
actions for civil contempt do not entitle the accused to trial by jury, ${ }^{207}$ the seventh amendment does not stand as a bar to administrative adjudication.

\section{CONCLUSION}

The sixth and seventh amendment rights to trial by jury have been zealously protected throughout the history of the American legal system. Their function has been to prevent unfair influence of politics, wealth, and government on the administration of our system of laws and justice. This policy cannot be easily displaced, no matter how laudable the goal. Summary administrative regulation undoubtedly has numerous advantages over the slow and often mexpert processes of the courts, but such practical considerations do not justify the constriction of constitutionally protected rights.

This Comment has sought to develop a general framework for determining when a money penalty can be administratively imposed, subject to only limited judicial review, without violating constitutional guarantees of trial by jury. The analysis has suggested that the right to jury trial will not bar administrative adjudication where the purposes of such procedures are consistent with the objective of administrative law-attaining prompt compliance with government regulations. As long as a penalty is designed to attam this compliance by compulsion rather than deterrence, civil procedure may be appropriate. Use of fimal administrative adjudications to impose civil money penalties which are not equitable in nature should be limited to the enforcement of specific orders where rapid adjudication is essential to effectuate a legislative policy.

267. See Michaelson v. United States, 266 U.S. 42, $64-66$ (1924); LIBRARY OF CoNGREsS, supra note 116, at 609-10; J. MOORE \ 38.33[3], at 266.1. 